\title{
The Dome of al-Sayyida Zaynab bint al-Hanafiyah at the Necropolis of Bāb al-Nașr in Cairo The problem of function and dating
}

\author{
Walīd Aḥmad Salah al-Dīn ${ }^{1}$
}

In the outskirts of Bāb al-Nașr, a brick dome is located in the southeastern edge of the cemetery ${ }^{2}$ dedicated to Sayyida Zaynab bint al-Hanafiyah ${ }^{3}$. The cemetery of Bāb al-Nașr can be seen north to Bāb al-Nașr and contains lots of tombs and graves for different characters such as historians such as the famous al-Maqrīzī, the Imām 'Abd al-Raḥman ibn Haldūn, the Imām Burhān al-Dīn ibn Zuqqā'ah in addition to the theologians, and $\overline{A l}$ al-Bayt or the prophet's Muhammad family ${ }^{4}$. The dome is attached to some remains of the tombs of the Sufis from its western side ${ }^{5}$. The mausoleum is wrongly thought by the neighboring people to be of the famous Zaynab, the daughter of Imām

\footnotetext{
${ }^{1}$ Lecturer- Tourism Guiding Department- Faculty of Arts- Ain Shams University.

${ }^{2}$ al-Maqrīzī, al-Mawā'izwa-l-i'tibar bi dikr al-hitatwa-l-Ātār, Released by Ayman Fu'ad Sayid, London, 2003, Vol,IV, Pt.II, p.918.

${ }^{3}$ The Ašrāf al-Hanafiyah known as the Muhammadans al-Muhamadiyinn they were directly related to Muhammadibn al-Ḥanafiyah, the son of 'Alī ibn Abī Tālib. See Muwafaq al-Dīn Ibn 'Uțmān, Muršid al-zuwwār ila qubūr al-abrār, Released by Muḥammad Fatḥ̄ Abu Bakr, Cairo, 1995, p.157.The sources mentioned the biography of the Sitt Zaynab from the Family of the prophet Muhammad and she is Zaynab bint Ahmad ibn Muhammad ibn 'Abd Allah ibn Ja'far ibn Muhammad ibn al-Hanafiyah ibn 'Ali ibn Abī Tālib. Al-Maqrīzī says "The commons called it-Mašhad al-Sitt Zaynab". The commons called it Ma 'bad al-Sitt Zaynab or the worship place. She was titled as al-Sitt Zaynab al-Muhmmadiyah. She visited Egypt with her brother who named Muhammad and she was buried in the cemetery of Bab al-Nașr. See al-'Ubaydalī al-Nassābah, Tārīh wa manāqib wa ma'ātir al-sitt al-tāhirah al-batūl al-Sayida Zaynab wa ahbār al-zaynabāt, released by Hasan Qāsim, Cairo, 1934, pp.86,87; Ibn alZayyiāt, al-Kawākib al-saiyyārah fì tartīb al-ziyārah fi-l-qarāfatayn al-kubrawa-l-șugra, Cairo, 1907, p.242 ;al-Maqrīzī, al-hitat, Edited by Ayman Fu'ad Sayid, Vol.IV, Pt.II, p.918; al-Sahāwy, Tuhfat al-aḥbāb wa bugiyat al-tullāb fi-l-hitatwa-l-mazārātwa-l-biqa $\bar{a}^{\prime}$ almubārakāt, Released by Ḥasan Qāsim, Mahmūud Rabīe , Cairo, 1937, p.40.

${ }^{4} \mathrm{Al}$ - 'Ubaydalī, al-Sayida Zaynab wa ahbār al-zaynabāt,, pp.86,87;Hasan Qāsim, al-Mazārāt al-Islämiyah, Bibliotica Alexandrina, 2018, p.165. The necropolis also housed the tombs of the famous Swiss Egyptologist Johann Ludwig Burckhardt who converted to Islam and changed his name to Sayh Ibrāhīm after he professed the Moslem Religion and he died in the year 1817AD at the age of 33. He was the one of the most enterprising and able of modern explorers of the East and the discoverer of the rock-hewn city of Petra. His tomb is purely Muhammadan character and his grave is a high oblong marble structure carrying his name. See Thomas. Edward and Mary Eliza, Syemour, George.L, Cemeteries and Mosque Tombs, Cairo, The Art Journal (1875-1887), New Series, Vol. 6 (1880), p.201;Galīla al-Qādīi, Alain Bonnamy, Architecture of the Dead, Cairo's Medieval Necropolis, AUC, Press, Cairo, 2007, p. 133

${ }^{5}$ Al-'Ubaydalī, al-Sayida Zaynab wa ahbār al-zaynabāt, p.87.
} 
'Alī ibn Abī Tālib ${ }^{6}$. The grave is bordered to the east by the huge square alQabaq ${ }^{7}$ which extends up to the citadel. Among the earliest domes built in the cemetery is the tomb of Badr al-Ğamālī and his son which is known as the dome of Šayh Yūnus 487AH/1094AD ${ }^{8}$.(Pl.I)

Al-Maqrīzī noted that "outside Bāb al-Nașr was a vast area except for a prayer place musala al- 'ìd which was built by Ğawhar al-Siqillī also the huge gardens of Raydān bustān Raydān with no traces of buildings until Badr alĞamālī was to be the first one who was buried in this place in 487AH/1094AD. The dome was prepared for him, later the people had their burials in this area for years after that" . One well known landmark beyond the city walls is a small mosque known as the musallah al- $i d$. It used to attract its largest crowd at 'id al-fitr, the festival of the Lesser Bairam, when the Fatimid caliph, leading a procession from the city, would come to pray with the congregation. It was here in the area surrounding the musallah al'i d that the first tombs of Bāb al-Nașr were built. ${ }^{10}$ The cemetery of Bāb alNașr is bordered by the Muqattam hills from the east, al-Ğayiš square to the north, Bāb al-Ši iriyah and al-Husayniyah to the west and Bāb al-Nașr to the south. The cemetery had various names according to the historical sources such as "the Sufis graves, the cemetery of Bāb al-Nașr, and the Sufis graveyard hawš al-șüfiyah ${ }^{11}$. Many Sufis wanted their burials to be closer to the $\bar{A}$ l al-bayt to gain their blessing. Therefore a grave nearby indicated the spiritual meaning for the Sufis and it is the place where the supplication for blessing was held ${ }^{12}$. It is this fact that made the people themselves want have their burials close to the tombs of Sufis also in order to gain the blessing ${ }^{13}$ from the Sufis on the one hand, and from the honorable $\overline{A l}$ al-bayt on the

\footnotetext{
${ }^{6}$ Muḥammad Zakī Ibrāhīm, Marāqid ahl al-Bayt fi-l-Qāhirah, Cairo, 2003, p.84

${ }^{7}$ A square located outside Bāb al-Nașr from the east and between al-Tugrah today Bulāq and the Nașr dome. It was named "the black square" or al-Maydān al-Aswad. It was prepared by Sultan al-Z̄āhir Baybars al-Saliḥ̄ al-Nağmī for the game of al-Qabaq; a huge structure mastabah was prepared for the archery. This game was played by his successors like alMasnșūr Qalāwūn and al-Ašraf Hualīl. For details see al-Maqrīzī, al-Hitat, III, pp.369-376.

${ }^{8}$ Al-Sahāwy, Tuhfat al-aḥbāb, p.40

${ }^{9}$ Al-Maqrīzī, al-Hitat, III, p.463. See also Muhammad Hamzah, Silsilat al-ğabbānat fi-l'imarah al-islāmiyah, wa Qarafat al-Qāhirah mi al-fatḥ al-islāmì ila nahāyat al-'aṣr almamlūkī, Cairo, 2006, pp.145,146.

${ }^{10}$ G.al-Qādīi, A.Bonnamy, Architecture of the Dead, p.129

${ }^{11}$ Tartwat Fathī al-Azharī 'Abd al-Șamad, Gabantbāb al-Nașr wa ru'iyā šāmilah li wad'aha 'alā harìtat al-siyāha al-diniyah wa-l-iršād al-siyāhn̄, PH.D thesis, Faculty of Tourism and Hotels, Menia University, 2016, p.22.

${ }^{12}$ M. Z. Ibrāhim, Marāqid Ahl al-bayt, p.84.

${ }^{13}$ Al-Maqrīzī, al-Hitat, IV, Pt.II, p.919
} 


\section{The Dome of al-Sayyida Zaynab bint al-Hanafiyah at the Necropolis of Bāb al-Nașr in Cairo The problem of function and dating}

other hand ${ }^{14}$. So the location played a vital reason in distributing the neighboring tombs and graves for the Sufis and also for the rulers from different eras as well as the imams, historians and travellers. To cut it short, neither al-Maqrīzī, nor to our knowledge and any other historian has specified its exact boundaries. But it is fairly safe to say that it didn't cover the entire area between Bāb al-Nașr and 'Abassiya because we are told that it became inhabited after 700AH/1301AD and the Mamluk worthies had their palaces, summer houses, and second homes which were built there. It is hard to tell whether those dwellings replaced any tombs or not as residential districts and burial grounds have always encroached upon each other in these parts. ${ }^{15}$

\section{The structure of the dome}

The dome is classified among the singular domes in Egypt which contains a grave inside and is covered by octagonal transitional zones and the dome's masonry which has eight semi-circular ${ }^{16}$ windows. The top of the dome was once provided with a crescent but it is now lost ${ }^{17}$. The semi-circular structure is $3.40 \mathrm{~m}$ high. The dome has six square opening used for the lighting purposes just to allow the sun light to come into the interior. (Pl.II). On the northern side, the dome structure is based on an octagonal drum acting as zones of transitions that are $1.50 \mathrm{~m}$ high. The drum has six sides; the northern and the southern are $2.60 \mathrm{~m}$ long, whereas the eastern and the western are $2 \mathrm{~m}$ long, which means that the octagonal drum has unequal sides which is unusual in the Islamic architecture (Fig.1). The dome has a polished surface while some traces of the original casing can be seen .The northern façade begins with the ground level of $1.70 \mathrm{~m}$ till the end of the square which is $5.40 \mathrm{~m}$ wide. The lower square begins with a square blind window opening

\footnotetext{
${ }^{14}$ In the outskirts of the cemetery, the Sufis of the Hānqāh sa 'ìd al-su 'adā' took about two acres for building a new cemetery that was turbat al-süfiyah and they enlarged the area after the year 790AH. The Mamluk emirs had their burials beside the tomb of Sufis such as Šams al-Dīn Qarāsunqur and the emir Sayf al-Dīn Kukāy, who had their graves facing the Sufis tombs, the emir Tājār al-Dawādār had also a grave in front of the Sufis tomb. Taštumur alSāqi had his burials beside the grave, in addition to the baths and the caravans that were built beside the Sufis graves. The Qabaq square maydān al-qabaq was still active until the death of sultan al-Nāsir Muḥammad ibn Qalāwūn. The scholars of Islam also had their burials bedside the tombs of Sufis and they were numerous in both Ayyubid and Mamluk periods. See al-Maqrīzī, al-Hitat, IV, Pt.II, pp.919-920; al-Sahāwy, Tuhfat al-aḩbāb, pp.31,32.

${ }^{15}$ G.al-Qāḍī, A.Bonnamy, Architecture of the Dead, pp.129,131.

${ }^{16}$ The researcher Tarwat al-Azhary noted that it contains eight semi-circular openings used for allowing the light entering inside the grave. See T.al-Azhary, Ğabānatbāb al-Nașr, p.119.

${ }^{17}$ Unfortunately there is no any old photo for the original form of the upper crescent; the current one is now made of wood and it seems to be added recently in unknown period.
} 
with four rows of circles. This window is unfortunately blocked and it seems that it was added in a later time. One meter higher, there is a small row of trilobed crenellations (Fig. 1/b); each unit is $40 \mathrm{~cm}$ high. To the east there is a qandìliyah or šand (Fig.1/a)with twin windows and a circular moonlike which is typically a Mamluk style. The oval opening is $40 \mathrm{~cm}$ wide each, while they are $90 \mathrm{~cm}$ high in each. The northern façade is overall $6.60 \mathrm{~m}$ high and overlooking some modern graves; the area that was once occupied by the cemetery of the Sufis ${ }^{18}$. By looking to this façade, the lower base is set adequate to the ground level with no debris in the lower part.

The western façade (Fig.2) (P1.III) is the main part from the structure and starts with the main entrance $2 \mathrm{~m}$ high, and $90 \mathrm{~cm}$ wide ${ }^{19}$. The main entrance is topped by an elegant row of trilobed crenellations. This row is set on the base of the octagonal drum of the dome which is the transitional zones which is $2 \mathrm{~m}$ wide from the west side. The twin windows qandìliyah or šand is set within the western side of the drum and each

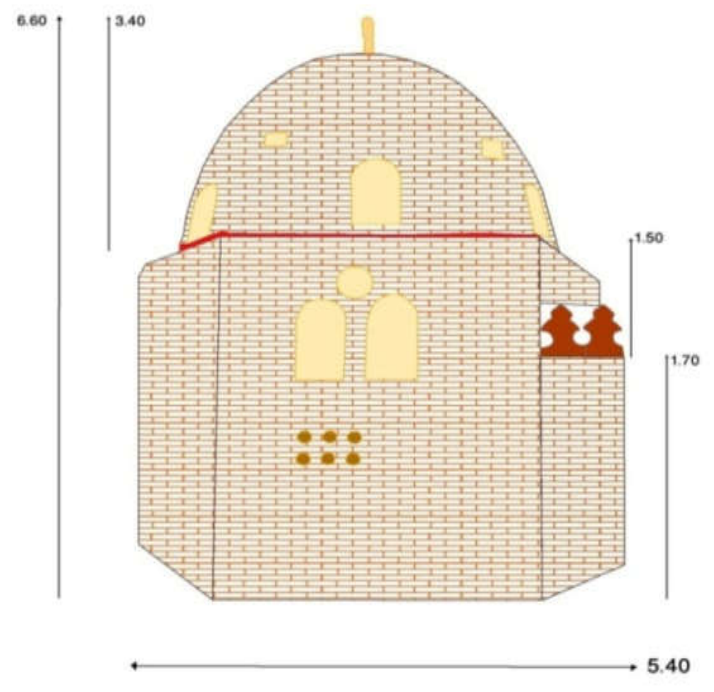

Fig.1

The northern façade- elevation and details

oblong opening is $40 \mathrm{~cm}$ wide and $90 \mathrm{~cm}$ high. The twin window is similar to that of the northern wall and also equal in size. The lower square part from the dome is $5.40 \mathrm{~m}$ wide while $2 \mathrm{~m}$ are hewn by a modern grave that was once occupied by the graves of the Sufis.

\footnotetext{
${ }^{18}$ Al-Sahāwy mentioned that on the north to the dome, there was a tomb for the Sufi $\check{S} a y h$ Muhammad al-Šahhāta al-Ğizāwy who was from the faithful men of his time as well as some other graves for unknown persons. See al-Sahāwy, Tuhfat al-aḥbāb, p.38.

${ }^{19}$ The researcher Tarwat al-Azhary mentioned wrongly that the door is only $1 \mathrm{~m}$ high and $60 \mathrm{~cm}$ wide see(T.al-Azhary, Ğabānatbāb al-Nașr, p.119 ), however, I gave accurate measurements with the help of a civil engineer while visiting the site and the dome.
} 


\section{The Dome of al-Sayyida Zaynab bint al-Hanafiyah at the Necropolis of Bāb al-Nașr in Cairo The problem of function and dating}

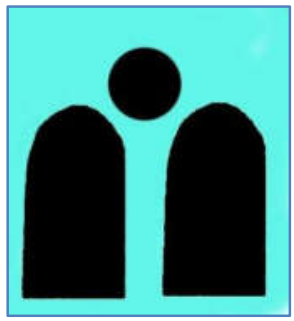

Fig.1/a

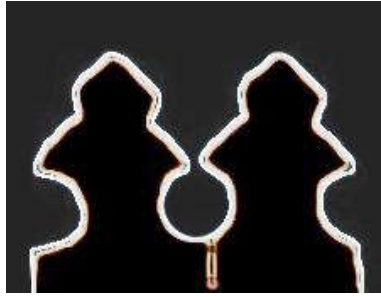

Fig. $1 / \mathrm{b}$

Details from the northern façade

The dome is set on the octagonal drum with no signs of decorations on its surface whilst three of the eight oval window openings are shown in this side. The portal's lower lintel is set higher than the interior of the building by $30 \mathrm{~cm}$ high. The main entrance seems to be newly restored by the cemetery's inhabitants ${ }^{20}$. The main entrance is provided with a modern wood door while the original one is lost in unknown period, while al-Sahāwy mentioned that the dome was provided with a door which had once the name of the rightly guided caliphs and other inscriptions carrying the date $1337^{21}$ and located in the desert of al-Mu 'alim Haiyrallah ${ }^{22}$. The façade is overlooking a modern grave $^{23}$ which was once a part of the ancient graves for the Sufis ${ }^{24}$. The façade is also overlooking Galāl Street and Bāb al-Nașr specially from the southwestern part of the wall.

The debris is set to $30 \mathrm{~cm}$ higher than the ground level and covers parts of the southern façade (Fig.3) (Pl.IV). The wall of the lower square part of the façade is $1.30 \mathrm{~m}$ high and extends to the octagonal drum which is also $1.50 \mathrm{~m}$ high. The overall façade is $6.20 \mathrm{~m}$ high looking much shorter than the northern one because of the accumulation of the debris. The entire façade still has some features as the twin window qandilliyah appears from the middle of the façade; each oblong is $40 \mathrm{~cm}$ surmounted by a moonlike qamarīyah to be $90 \mathrm{~cm}$ high totally. The revetment of the octagonal drum is shown partly

\footnotetext{
${ }^{20}$ The entrance is paved with white encasement seems to have been restored in unknown period. By examining the type of casing it seems to be put in a modern ages over the original surface of the door's masonry.

${ }^{21}$ Al-Sahāwy didn't mentioned the type of the date wither it is hijrī or Anno Dommini. But If we considered it in $\mathrm{AD}$ formula, it means that this dome was restored in the time of the Mamluk sultan al-Nāșir Muhammad ibn Qalāwūn because 738AH/1337AD that is the last years of his third reign (see Zambaur. Edward Von,Mu '⿳̆am al-ansāb wa-l-usrāt al-hākimah fi-l-tārīh al-Islämī, Beirut, 1980, p.163). But when taking the date 1337AH/1918AD as it is the hijrī, that indicates that the date is the reign of King Fu'ad I (see Zambaur, Mu'gam alansāb, p.167) and the dome was restored within his rule.

22 al-Sahāwy, Tuhfat al-aḥbāb, p.38

${ }^{23}$ T.al-Azhary, Ğabānatbāb al-Nașr, p.119

${ }^{24}$ al-Sahāwy, Tuhfat al-aḥbāb, p.38
} 
damaged especially from the western side whereas the eastern part from the façade is being covered with a modern wooden grave as the wall of the mihrab has also disappeared. Three from the eight oval window openings are shown in the façade while the upper semi-circular dome has a polished surface and nothing has remained from the original casing. The row of the crenellations is totally damaged. Parts of the rectangular window are shown in the lower part from the dome. As for the eastern part, it is completely hewn behind a modern grave ${ }^{25}$ which is unreachable in the meantime. This part is fully covered from behind with the mud brick wall

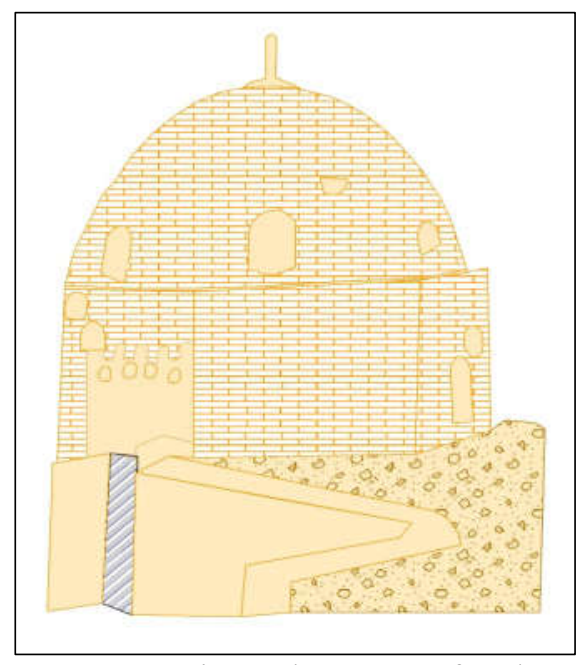

Fig.2. The western façade

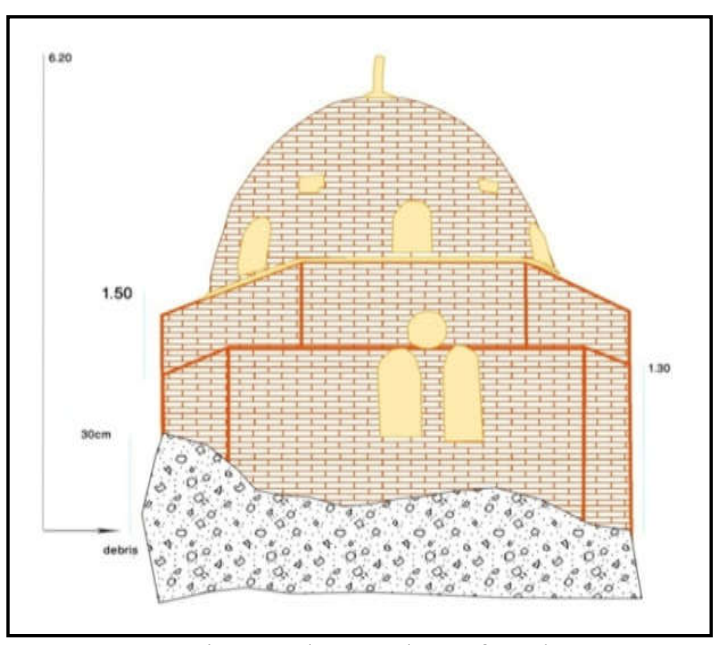

Fig.3. The southern façade and a modern grave that makes the architectural elements disappeared. When observing the façade; great part of it is covered with a smoothed mortar casing while some trilobed crenellations which appears from the western side seems to have been newly restored.

The main entrance is on the southern side of the western façade and leads to the interior hall of the dome. The plan is almost square and the diameter of the dome is $3.75 \mathrm{~m}$. The western wall is void of decoration except for the twin window qandiliyah. The wall also has a square opening used for entering the light into the interior chamber. On the right side of the southern wall, two wooden benches for the Quran reciter are shown and are badly preserved. The first one is $110 \mathrm{~cm}$ high and $160 \mathrm{~cm}$ wide $(\mathrm{Pl} . \mathrm{V})$, has its upper balustrade is decorated with fine wooden inlays. The sides of the chair are

\footnotetext{
${ }^{25}$ In order to recognize the outer wall from the qibla, I need to remove a great part from the modern wooden graveyard that is mainly attached to the building and also it is hard to reach the inner wall to see if the mihrab has a protruding buttress or not. This façade must have contained the twin window qandiliyah such as the northern and the southern facades also to be in a harmony with the other remaining facades.
} 


\section{The Dome of al-Sayyida Zaynab bint al-Hanafiyah at the Necropolis of Bāb al-Nașr in Cairo The problem of function and dating}

decorated with vertical rectangular inlays. The other chair (Pl.VI) beside it is slightly smaller and $90 \mathrm{~cm}$ wide, $1 \mathrm{~m}$ high. It has only one back stand with no balustrade while the sides are void of decorations. In the center of the wall, a rectangular airshaft malqaf is shown with circular halls (Pl.VII) and it seems to have been added in a later period than the date of the dome and used for cooling the area of the reciter. A twin window qandiliya is shown above the airshaft. The same devices are shown on the opposite wall from the north side, while the twin window qandilliyah is shown above the square base. A rectangular recess is set underneath the window which seems to have been used as a cupboard kutbiyah ${ }^{26}$ for the books and the Quran (Pl.VIII), or it was just a window opening and blocked in unknown time. The base of the dome rests over only four squinches as transitional zones. The style of the squinches seems to have been used in the early times mainly before the Mamluk period. (P1.IX)

The eastern wall comprises the mihrab (Fig.5) which is a niche $180 \mathrm{~cm}$ high, $90 \mathrm{~cm}$ wide and $50 \mathrm{~cm}$ deep $(\mathrm{Pl} . \mathrm{X})$, and it is of brick and the cavity is located in two recesses and topped by two semi-circular arches. The mihrab has some scratches which indicate that this mihrab was once covered by a marble coating. The mihrab is topped by a circular oculus that was once opened to the eastern part and is now blocked because of the grave that is mainly attached to the dome on the back side. It is hard to know wither this oculus was once filled with stucco grills or not. The oculus is surmounted by a square opening ${ }^{27}$ and seems to have been used for entering the light like the other four sides from the hall. The hall of the dome doesn't contain a grave or any sign of a structure, but a marble slab has been found (Pl.XI) carrying nashī inscriptions indicated that this grave was constructed for a lady. The style of the inscription is somehow modern. The ceiling is vaulted while there are eight oval windows running all around the base of the dome. When observing the vertical sector of the dome. The entire plan is square $5.40 \mathrm{~m}$ in the diameter of each side, then the octagonal drum $2.60 \mathrm{~m}$ wide from south to north and $2 \mathrm{~m}$ from east to west.

\footnotetext{
${ }^{26}$ A recess is the hall contained a wood cupboard used for preserving the books and also used for preserving the paper rolls and the artifacts. This device used in most of the religious institutions like the mosques, madrasas, and Ḩanqāwāt. See Layla 'Alī Ibrāhīm, Muhammad Amīn, al-Mușțalāhāat al-mi 'mārìyah fi-l-wațā'iq al-mamlūkīyah, The American University in Cairo, 1990, p.93.

${ }^{27}$ This device is rare to be found in Islamic architecture
} 


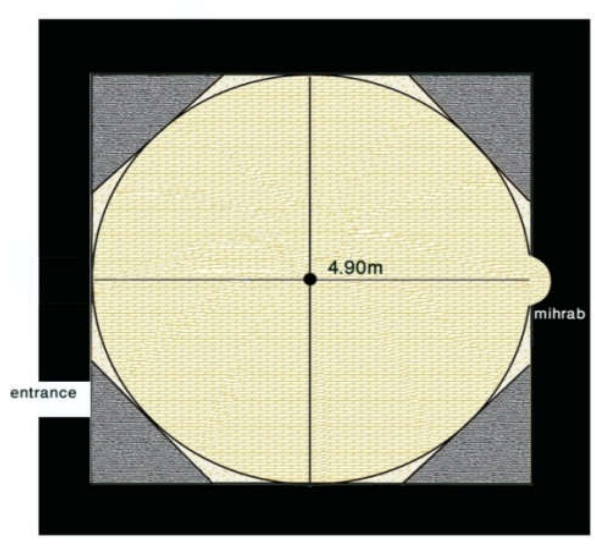

Fig.4

Dome of Sitt Zaynab-Plan

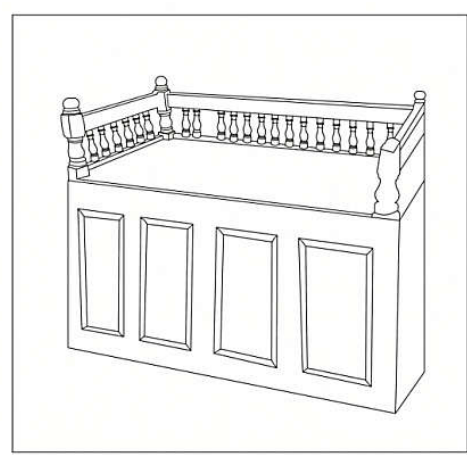

Fig.6

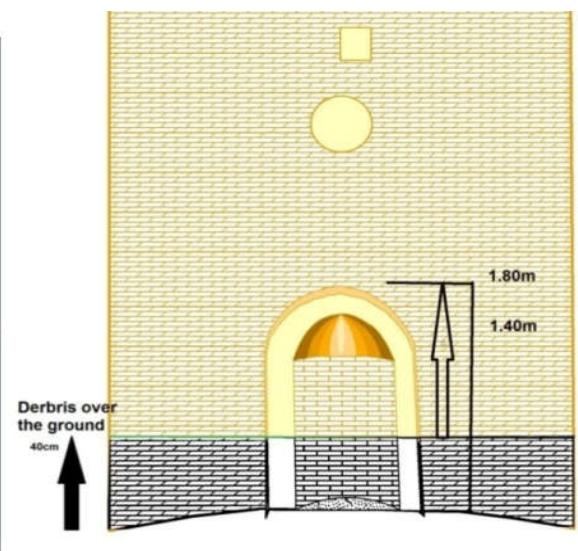

Fig.5

the qibla wall-mihrab

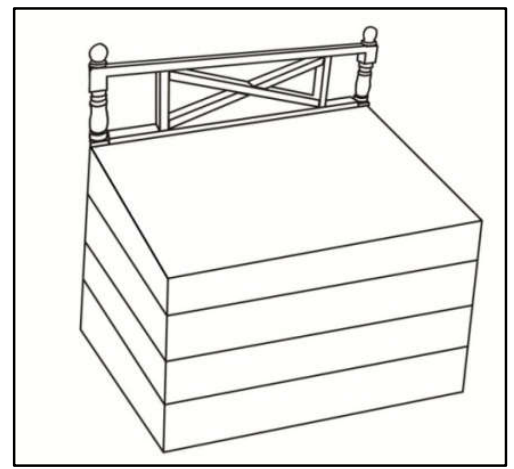

Fig.7

Chairs for the quran readers

The mihrab's cavity has no external projection. According to the plan, the entrance is located in the southwestern part, while the upper dome is resting on the octagonal drum. (Fig.4).The other remaining axial points of the octagonal drum are also $2 \mathrm{~m}$ wide each. The last point of the sector is the circular dome structure which is $3 \mathrm{~m}$ in diameter, while the base consists of a row of eight oval windows for the light. Three artifacts were found in the interior of the dome; the first is the marble slab contains an inscription. The second is two wood chairs for the reciter located attaching the southern wall of the interior dome. The first device is a marble slab which contains three lines of the nashī inscriptions reads: (Pl.XII) (Fig.7/a). 


\section{The Dome of al-Sayyida Zaynab bint al-Hanafiyah at the Necropolis of Bāb al-Nașr in Cairo The problem of function and dating}

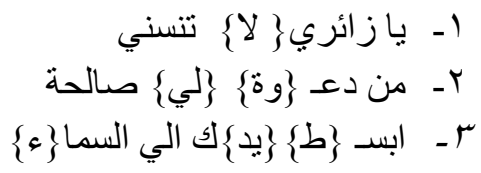

1- Oh, my visitor do not forget

2- a true prayer for me

3- hold your hands up to the heaven

The slab is of marble $(30 \times 45 \mathrm{~cm})$. The words are inscribed in Nashī inscriptions which are partly damaged. It carries some invocations and demands from the deceased to who will visit his or her grave. This formula is very unique to be found in the Islamic Architecture especially the formula itself and the demand "Oh my visitor don't forget" "hold your hands up to the heaven". The style of writing here indicates that it was applied in later times may be a Mamluk or Ottoman times or even in the time of the Muhammad Ali dynast in the modern ages,

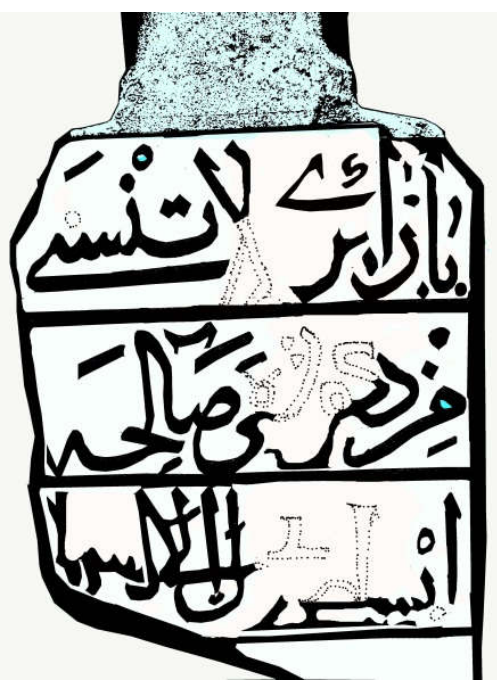

Fig.7/a marble slab with inscriptions

because the nashī was not found in the $3^{\text {rd }}$ century of hijrah the time when she came to Egypt. Moreover, the nashī inscriptions occurred in the $6^{\text {th }}$ Century $\mathrm{AH} / 12 \mathrm{AD}^{28}$. The second artifact is a chair for the reciter (Fig.6). The first one to the left is $110 \mathrm{~cm}$ high and $160 \mathrm{~cm}$ wide. It is made of wood but the question is when it was made and by whom? . From the style of the chairs they seem to have been made in a period after the Mamluks because the style is strange somehow.

\footnotetext{
${ }^{28}$ This type of cursive nashī inscriptions could be father estimated that it is occurred for the first time in Islamic architecture in India in the mihrab of the mosque of Quṭb Manār 590AH/1193AD which represents the witnessing formula (see Dominique Clévenat, Splendors of Islam, New York, 2000, pp.151, 153. P1.210). In Egypt, the Nashī was used firstly in the end of the Fatimid Period, especially in the tissue fragments, onwards showing more evidence on these words as a beginning of using the cursive script Nashi or al-Hatt alLayin or al-Muqawar over artifacts displayed in the Fatimid tissue of the $3^{\text {rd }}$ style in a tissue fragment from the $6^{\text {th }} \mathrm{AH} / 12^{\text {th }}$ AD.see Shimmel, Annemarie, Calligraphy and Islamic Culture, New York, 1984, p.12;Ahmmad 'Abd al-Rāziq, al-Funūn al-Islāmiyah hata nahāyat al-'Așr al-Fațimī, Cairo, 2006, p.192.
} 
The chair has a small balustrade as a support for the reciter's back which is applied in a wood assembly technique. This type of chairs was known in the Mamluk period but it took different styles. According to the Mamluk documents, the imam has his special rank in the Mamluk period while the waqfiyah of the madrasah of the sultan Hasan mentioned the position of the imām who gained his monthly salary of about 60 dirhams $^{29}$. The dome of the madrasah provides a chair for the imam that hasn't been mentioned in the document (Pl. XIII) which means that it was put in a later period than the date of the madrasah because the style is not a Mamluk $^{30}$. According to the documents, none of them mentioned this device before. Also they have not been discovered in the Mamluk period which means that it was probably made in the $19^{\text {th }}$ century $\mathrm{AH}$, and they were given as a donation for the mosques. Another chair is behind the first with a primitive and simple style (Fig.7)

\section{The architectural analysis}

The dome is classified as a separate burial dome ${ }^{31}$ used to bury the honored persons and the structure is almost square from the lower edifice as seen in most of the ancient domes such as for the records like the ancient dome of al-Sulaībiyah 245AH/862 used for the burial of the Abbasid caliph al-Muntasirir $^{32}$. In Egypt, the oldest style of the separate domed mausoleums could be the separate dome of ȚabāṬabā $334 \mathrm{AH} / 943 \mathrm{AD}^{33}$. In the dome of Sitt Zaynab, the plan and elevation (Fig.4) starts from a square $5.40 \mathrm{~m}$ wide, then octagonal transitional zones, then ends with the circle of the dome which has a $4.90 \mathrm{~m}$ in its diameter. The earliest types of separate domes have started with the square structure and are supported directly to the circle to be the

\footnotetext{
${ }^{29}$ Huwayda al-Hārițī, Kitāb waqf al-sultān Hasan bin Muhammad ibn Qalāwūn 'alā madrasatihī bi-l-Rumaylah, Bairut, 2001, p.156, lines 15, 18.

${ }^{30}$ In the Mamluk style, the most elaborate designs shown are some inlaid star patterns especially that shown in the Quran chairs as seen in the inner dome of the madrasah of sultan Hasan. The Waqf mentioned that there were more than 60 Quran readers in the dome working in rotational shifts and they had their own salaries. Also there was a special readerfor the Quran in Friday. See H.al-Harițī, Waqf al-sultān Hasan, pp.158,159.

${ }^{31}$ T.al-Azhary, Ğabānatbāb al-Nașr, p.119.

${ }^{32}$ Șālih Lam'ī Muștafa, al-Qibāb fi-l-'Imārah al-Islāmiyah, Cairo, no date, p.24; Aḥmad

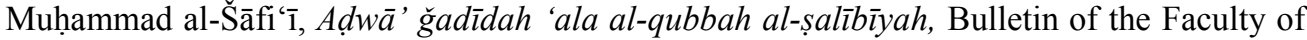
Arts, Sohag University, April, 2018, No,47, Volume I, p.411.

${ }^{33}$ Creswell.K.A.C, Muslim Architecture of Egypt, Oxford, 1952, Vol.I, p.12; Muhammad Hamzah, al-Qibab fi-l-'Imarah al-Mișriyah al-Islāmīyah, Cairo, 1993, p.39.
} 


\section{The Dome of al-Sayyida Zaynab bint al-Hanafiyah at the Necropolis of Bāb al-Nașr in Cairo The problem of function and dating}

earliest method of supporting dome ${ }^{34}$. The new device was added to separate between the square from the circle which are the zones of transition; this style occurred firstly in the Persian architecture ${ }^{35}$. The style is applied in most of the earliest Fatimid domes in Egypt in the seven Fatimid domes in alMuqattam $400 \mathrm{AH} / 1010 \mathrm{AD}^{36}$. The structure of those domes begins with two squares and an octagonal drum as a transitional zone which are built of bricks and consists of a window in the center of each face. The lower two squares are built of bricks with openings supported by semi-circular arches ${ }^{37}$. The dome of Sitt Zaynab was built on the same structure but with only one square, an octagonal drum and the dome. The construction of the square then the octagon are typically shown in the early Fatimid mausolea like that of alSayyida 'Atikah and al-Ja'fari $515 \mathrm{AH} / 1121 \mathrm{AD}^{38}$. Also the style of the octagonal drum is seen in the dome of Ihwat Yūsuf $6^{\text {th }} \mathrm{AH} / 12^{\text {th }} \mathrm{AD}^{39}$.

The previous statements show that when looking to the drum in the dome of Sitt Zaynab, the style occurred in the $4^{\text {th }}$ to $6^{\text {th }}$ centuries $\mathrm{AH} / 10-12^{\text {th }} \mathrm{AD}$ and could be seen clearly in the dome of TabāṬabā which is the earliest example. Also the style of the lower square structure is shown from the $3^{\text {rd }}$ $\mathrm{AH} / 9^{\text {th }}$ AD century. The dome over the two lower levels over the grave of Sitt Zaynab has eight semi-circular windows; each one faces one side of the octagonal drum. The upper structure is not purely semi-circular as if it is spanning the center of few centimeters from the center of the circle as it is an oval dome not semi-circular; a prototype seen in the dome of TabāṬabā ${ }^{40}$. By this way, the style of the upper domed structure is mostly primitive someway made in the early ages. The style of the second octagonal level has taken different style. The drum has an octagon that is mainly occurred in some

\footnotetext{
${ }^{34}$ Ahmad Ali El Khateeb, Domes in the Islamic Architecture of Cairo city, A Mathematical Approach, in Nexus Netw J 14, Vol.14, No.1, Turin , Jan.2012, p.156.

${ }^{35}$ Jawdat Goussous, Wael al-Azhari, Domes Formation in Mediterranean Islamic Countries, Conference: "DOMES IN THE WORLD" International Congress November 3-6, 2011 Florence, ITALY, pp.7-8.

${ }^{36}$ Creswell, M.A.E, I, p.13, fig.6; M.Hamzah, al-Qibab, p.40

37 'Abdallah Kāmil Mūsa, The Fatimid Architecture in Cairo, Cairo, 1995, pp.45,46, Pls.59,60.

${ }^{38}$ Yūsuf Rāgìib, Les mausolées fatimides du quartier d'al-Mašāhid, Annales Islamologiques IFAO, Le Caire, 1971, Tome 17, p.12; A. K. Mūsa, The Fatimid Architecture, p.51.

${ }^{39}$ Mamdūḥ Muḥammad Ḥasanayn, al-Mašāhid al-bāqiyah fi-l- 'Aṣr al-Fātimì̄, M.A, Faculty of Archaeology, Cairo, University, 2003, pp.146,147, P1.52.

${ }^{40}$ Creswell, M.A.E, I, p.13, fig.6.
} 
Fatimid architectural buildings that is shown in the dome of Sayyidah "Ātikah and al-Ja'farī while the drum is opened by a "Y" shaped window ${ }^{41}$. The lower square structure has taken also a different style, the only difference is the style of the windows like the $\check{S}$ and or Qandiliya ${ }^{42}$ which also appears in the dome of Abu-1-Qāsim al-Tayib (mid $6^{\text {th }} \mathrm{AH} / 12^{\text {th }} \mathrm{AD}$ ) from the Fatimid period, but the device here takes different form as the top of the qamariyah is triangular. ${ }^{43}$ In the dome of Sitt Zaynab, the device is mainly Mamluk styleand seen in one of the Bahrite separate domes in Egypt such as the dome of Tatar al-Hiğāziyah748-761AH/1348-1360AD, whiles the šand or qandiliyah is set on the base of the octagonal drum ${ }^{44}$, and also in the dome of Tankazbuga $760 \mathrm{AH} / 1359 \mathrm{AD}^{45}$. The same profile of windows is applied on some of the Mamluk domes at the northern cemetery șaharā'; such as the dome of Ğānibak al-Ašrafī (before 831AH/1437AD) ${ }^{46}$.Similar to the dome of Sitt Zaynab, the šand is located on the basement of the octagonal drum and they are embedded in the masonry in each façade of the dome. Generally, the Idea of opening a window in the octagon drum of the dome appeared firstly in the Iranian domes such as the tomb of Imāzāda Yahiyā at Varāmīn, while

\footnotetext{
${ }^{41}$ Y. Rāgib, Les mausolées fatimides, AnIsl, 17, p.12 ;Williams, Caroline. "The Cult of 'Alid Saints in the Fatimid Monuments of Cairo Part II: The Mausolea.” Muqarnas, vol. 3, 1985, p.42, Pls.2,3;El Sandouby, A.,Ezzeldin Ismail, The Ahl al-Bayt n Cairo and Damascus: The dynamics of making shrines for the family of the prophet, PHD, University of California, Los Angeles, 2008, Figs.3.13,3.14.

${ }^{42}$ A Type of circular moonlike once covered with stucco grills. It has different forms and shapes; some have oblong shapes and the others are circular. The two oblong windows under

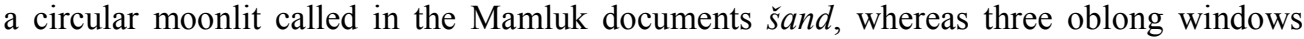
under three moonlikes called dūst. See L.A.Ibrāhīm, Muḥammad Amīn,m al-Muṣtalaḥāt almi 'māriyah, pp.91,92.

${ }^{43}$ G.al-Qādị̄, A.Bonnamy, Architecture of the Dead, p.56

${ }^{44} \mathrm{Aḥmad}$ 'Abd al-Rāziq, Un collège féminine dans l'Egypte Mamluke, Journal of the Faculty of Archaeology, Cairo University, Part III, 1987,P1.II/B ;Cipriani. Barbara, Development of the Construction Techniques in the Mamluk Domes of Cairo, M.A, Massachusetts Institute of Technology, 2005, p.40. Fig.1.7

${ }^{45}$ M.Hamzah, al-Qibab, P1.94.

${ }^{46}$ Hānī Hamza, The Northern Cemetery of Cairo, The American University in Cairo, 2001, Pl.16
} 


\section{The Dome of al-Sayyida Zaynab bint al-Hanafiyah at the Necropolis of Bāb al-Nașr in Cairo The problem of function and dating}

the drum is usually much thicker than the dome ${ }^{47}$, the same form here in the dome of Sitt Zaynab while the octagonal drum is almost thicker than the arch of the dome. Certainly, the arch of the dome is classified as pointed arch in the consideration of exact typology of external shell profile and this style occurred in the Middle East and central Asia ${ }^{48}$.The northern façade in the dome of Sitt Zaynab is enhanced by a small course of trilobed crenellations (Fig.1/a), and this device is certainly Mamluk because the style of the trilobed leave in each unit occurred in the Mamluk period over their edifices as seen for example in the dome of Kuzal al-Nāșirîn ${ }^{-49}$.

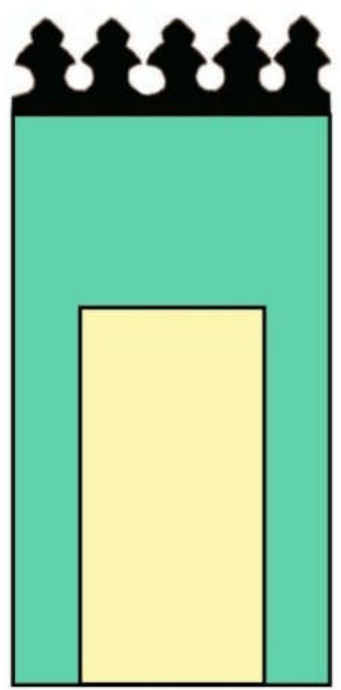

Fig.8

The western entrance

This course with the same style of ornaments could be also seen in the dome of Tatar al-Hiğāziyah ${ }^{50}$, because, this style of trefoil crenellation was never found before the Mamluk period and it occurred for the first time in the tulunid period in the mosque of Ibn Tulun but was such parapets that turns out to be a repetition of Samarra Stucco motifs ${ }^{51}$.In the dome of Sitt Zaynab,

\footnotetext{
${ }^{47}$ D. H. Gye. "Arches and Domes in Iranian Islamic Buildings: An Engineer's Perspective." Iran, vol. 26, 1988, p.142, Pl.11a.

${ }^{48}$ Ashkan, Maryam. \& Ahmad, Yahaya, Discontinuous Double-shell Domes through Islamic eras in the Middle East and Central Asia: History, Morphology, Typologies, Geometry, and Construction, Nexus Network Journal - Vol.12, No. 2,Turin, 2010, pp.304,307.

${ }^{49}$ M.Hamzah, al-Qibab, Pl.104. H.Hamza, The Northern Cemetery, P1.35.

${ }^{50} \mathrm{~A}$. 'Abd al-Rāziq, Un Collège féminin, pp.16,18, Fig.5, Pl.II/A ;O’Kane, Bernard. "The design of Cairo's masonry domes." Proceedings of the Masons at Work

Conference.University of Pennsylvania, 2012, p.6, Fig.6.

${ }^{51}$ Doris. B.Abu Seif, Islamic Architecture, An Introduction, AUC, Cairo, 1989, p.53, P1.40; Munazamat al-'awașim wa-l-mudun al-Islāmiyah, Usus al-tașmìm al-mi 'mārīwa-l-tahțīt alhaḍarī fi-l-'uṣur al-islāmiyah al-muhtalifah bi-l-'āșimah al-Qāhirah, Cairo, 1990, p.21, Fig.3/220; Swelim. Muhamad Tarek Nabil, The Mosque of IbnṬūlūn, A new perspective,= 
here in the western main façade mainly over the main entrance, another course of crenellations occurred, and it seems that was restored and had a new painting. Thus the dome of Sitt Zaynab gathers different styles from different periods. Before entering the tomb, the style of the entrance is uncommon. The entrance masonry is located on the southwestern side of the western façade which is a rectangular opening (Fig.8) crowned by five units of trilobed crenellations. The style of this entrance is almost unique in Islamic architecture especially when finding an entrance with a course of crenellations over the lintel. But we are able to see some traces of these types of crenellations on the upper walls of the dome of al-Ṣawābi $684 \mathrm{AH} / 1285 \mathrm{AD}^{52}$

The crenellations here are in the form of trilobed leaves and they are continued on the four walls of the tomb. Other traces of those types occur in the northern façade of the edifice (Fig.1/a). From the main entrance the interior chamber is almost square in shape and the most striking element to the eyes are the four squinches muqarnas ${ }^{53}$ on the four corner of the drum as transition zones. The style of the squinches is mostly primitive which makes us confused about their dating and the dating of the grave. On the four corners of the interior hall, the dome rests over a drum of four simple squinches. The style of the squinches is almost simple with semi-circular top and curved lower edge (Fig.9) the style that occurred in the early $3^{\text {rd }} \mathrm{AH} / 6^{\text {th }}$ $\mathrm{AD}$ century specially in the $b a b$ al-'Amah in the palace of al-Mu'tașim known as Jawsaq al-Hāquān at Samarrā' $221 \mathrm{AH} / 836 \mathrm{AD}^{54}$ like those of the

$=\mathrm{PhD}$, Harvard University, 1994, p.3 ; Ibn Tulun, His Lost City and Great Mosque, AUC, Cairo, 2015, Fig.8; Aḥmad 'Abd al-Rāziq, al-'Imārah al-Islāmiyah fì Miṣr mundِu al-fath al'arabī hata nahāyat al- 'aṣr al-mamlūkī, Cairo, 2012, p.51.

${ }^{52}$ M.Hamzah, al-Qibab, P1.77

${ }^{53}$ An architectural stalactite vaulting in a form of a honey comb was used to embellish the buildings, cornices and the transitional zones of the domes. Each unit is called a squinch hațah in a form of a small niche with pointed or semi-circular arch. The muqarnas has several types like $a l-s \bar{a} \bar{m} \bar{\imath}$ or from the Levant which has a semi-circular arch, and the native types al-baladī in a form of keel arched squinch. See L.A.Ibrāhīm, MuḥammadAmīn,malMuștalahăt al-mi 'māriyah, p.113. The first type of Muqarnas motif first appears in Egypt in the cornice of the minaret of Badr al-Ğamālī's Mašihad on the muqattam hills 478AH/1085AD . See Bloom. Jonathan M, The Introduction of the Muqarnas into Egypt, Muqarnas, Brill, Vol. 5 (1988), p.21.

${ }^{54}$ Northedge Alastair "An Interpretation of the Palace of the Caliph at Samarra (Dar AlKhilafa or Jawsaq Al-Khaqani)." Ars Orientalis, Freer Gallery of Art, The Smithsonian Institution and Department of the History of Art, University of Michiganvol. 23, 1993,= 


\section{The Dome of al-Sayyida Zaynab bint al-Hanafiyah at the Necropolis of Bāb al-Nașr in Cairo The problem of function and dating}

dome of Sitt Zaynab that means that this style of squinches occurred in the domes of the $3^{\text {rd }}$ century $\mathrm{AH}$ in the same style of the semi-circular arch and only one squinch is set on the triangular pendentives and the squinch has a deep cavity to the walls of the drum from the other side (Fig.9/a). In Egypt, the oldest dated example could be seen in the dome over the mihrab of the mosque of al-Hākim bi' Amr Allah 380-403AH/990-1131 AD ${ }^{55}$.

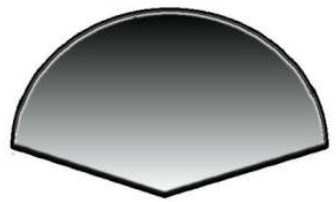

Fig.9

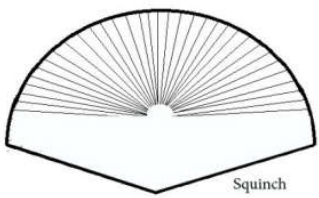

Fig.9/a

Squinches in the dome of Sitt Zaynab

Drawn by the researcher

This style of squinches also occurred from the beginning of the $5^{\text {th }} \mathrm{AH}$ century in the domes of the Fatimid period especially in the domes of saba banāt in the outskirts of Muqattam ${ }^{56}$. The domes are represented in a simple form with almost one semi-circular squinch in the dome over the mihrab in the prayer hall of the mašhihad of al-Ǧiyūšs̄ $478 \mathrm{AH} / 1058 \mathrm{AD}^{57}$. One unit of squiches was put also in the transition zones of the Fatimid dome of al-Hafiz at al-Azhar mosque ${ }^{58}$, and the dome of Ihawat Yūsuf $6^{\text {th }} \mathrm{AH} / 12^{\text {th }} \mathrm{AD}$, the drum is embedded with only one unit of squinches in each side ${ }^{59}$ also in some of the Fatimid domes in Aswan City that the domes has a drum of one unit of squinches without any external projection ${ }^{60}$. The same from of squinches are also seen in the dome of Mufy al-Dīn (mid $5^{\text {th }} \mathrm{AH} / 11^{\text {th }} \mathrm{AD}$ ), and the dome of Abu Turāb at al-Abbasiyah ${ }^{61}$; the style that resembling that of the palace of al-Mu'tașim which is considered the first of its type in Islamic

=p.146; Farīd Šāif'î, al- 'Imārah al- 'arabiyah fì Miṣr al-Islāmiyah, 'Aṣr al-wullāh, General Egyptian Book Organization, Cairo, 1994, pp.144,402, Figs.91, 233.

${ }^{55}$ Delly. Wilfred Joseph, al-'Imārah al-'arabiyah bi Miṣr, fïšarh al-mumayzāt al-binā'iyah al-ra'̄isiyah li-l-țirāz al- 'arabī, Cairo, 1923, p.19.

${ }_{56}$ Creswell, M.A.E, I, p.13, Fig.6; Amāl al-'Imarī, al-'Imarah al-fațimiyah, no date, pp.72,73. See also http://www.islamic-art.org/CreswellExhibition/index.htm

Briggs. Martin.S, Muhammadan Architecture in Egypt and Palestine, Oxford, 1924, p.71, Fig.38.

${ }^{58}$ Creswell, M.A.E, I, Pl.113c; O’ Kane, Domes, p.17, Fig.27.

${ }^{59}$ Creswell, , M.A.E, I, pp.234-235.

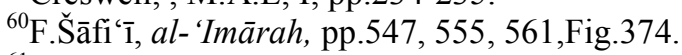

${ }^{61}$ Ibrahim.Layla.A, The Transitional Zones of Domes in Cairene Architecture, Kunst des Orients, Franz Steiner Verlag, Vol. 10, H. 1/2 (1975), p.6 
Architecture $^{62}$.To sum up, the muqarnas squinches in the dome of Sitt Zaynab has a style somehow primitive with smoothed cavity with no conical form and most probably recalls the style of the $3^{\text {rd }} \mathrm{AH} / 9^{\text {th }} \mathrm{AD}$ century which is also continued in the $4^{\text {th }}-5^{\text {th }} / 10^{\text {th }}-11^{\text {th }} \mathrm{AD}$ centuries. Obviously one can exclude the Ayyubid and Mamluk periods as periods of construction; such as the dome of Imām al-Šafi' ${ }^{\prime} 1608 \mathrm{AH} / 1211 \mathrm{AD}^{63}$, and the dome of Šağar al-Durr $648 \mathrm{AH} / 1250 \mathrm{AD}$ have three-tiered squinches as transition zones, while the two-tiered course of squinches could be seen in the dome of the Abbasid caliphs ${ }^{64}$. In the Bahari Mamluk period, more than two and three tiers of squinches can be seen in al-Manșūr Qalawūn's dome (683-4AH/1284AD), which also resemble that of the mausoleum of al-Ašraf Halīil(687AH/1288AD) ${ }^{65}$

Underneath is the main mihrab which is located in the center of the Qibla wall and surmounted by an oculus and a rounded window opening (P1.)(Fig.5). The mihrab is made of brick and the inner core is of mudbrick, indicating that this mihrab was once restored in a certain period of time. The style of the mihrab and the oculus is mainly seen in the Mamluk qibla walls, while mostly all the separated domes in the Mamluk period had their mihrabs made of stone. The mihrab has almost one recess with a style somehow old with no external projection. If we look to the style of the Fatimid mihrabs, the upper hood has a keel arch as seen in the mihrab of the mausoleum of al$\mathrm{Lu}^{\prime} l$ ' $^{\prime} \mathrm{h}^{66}$, also in the mihrab of the mausoleum of Ihwat Y ūsuf ${ }^{67}$, and they had a conch with ribbed hoods like sunrays as seen in the mihrab of alSayyida Ruqayyah ${ }^{68}$, and they are also covered with carved stucco ornaments as seen in the mihrab of the mašihad al-Ǧiyūšš ${ }^{69}$. Here in the mihrab of the

\footnotetext{
${ }^{62} \mathrm{~F} . \breve{S a ̄ f i}{ }^{‘} \overline{1}$, al- 'Imārah, p.561

${ }^{63} \mathrm{Creswell}$ Photo Archive in the Ashmolean Museum.

http://creswell.ashmus.ox.ac.uk/archive/EA.CA.4406-0; Mulder.Stephennie, The Mausoleum of Imam Al-Shafi 'i, Muqarnas,Vol. 23 (2006), p.19, Fig.6; A. 'Abd al-Rāziq, al- 'Imārah, p. 169.

${ }^{64} \mathrm{~A}$. 'Abd al-Rāziq, al-'Imārah, p.201

${ }^{65}$ Ibrahim.Layla.A, The Transitional Zones, KunstOr, 10, p.9

${ }^{66}$ A. K. Mūsa, The Fatimid Architecture, p.47, P1.66

${ }^{67}$ Creswell, M.A.E, I, pp.234-235; A. K. Mūsa, The Fatimid Architecture, p.58, Pl.74

${ }^{68}$ Y. Rāgib, Les mausolées fatimides, AnIsl, 17, p.21; Pruitt Jennifer. A, Fatimid Architectural Patronage and Changing Sectarian Identities (969-1021), PhD, Harvard University, 2009, p.295, Fig.5.7.

${ }^{69}$ The stucco revetment is now lost. See A. 'Abd al-Rāziq, al-'Imārah, p.110
} 


\section{The Dome of al-Sayyida Zaynab bint al-Hanafiyah at the Necropolis of Bāb al-Nașr in Cairo The problem of function and dating}

dome of Sitt Zaynab, the style is different. While the mihrab has a cupola enhanced by two semi-circular arches, without any sign of flanked columns; they may have been lost in an unknown period. Thus it is hard to estimate if this mihrab was built in the Fatimid period because the style is not Fatimid of course. In most of the Mamluk domes, the mihrabs are made of stone and they are surmounted by an oculus as seen in the dome chamber in the madrasah of sultan Hasan ${ }^{70}$. The style of the qibla wall is seen in the Mamluk period as a mihrab surmounted with an oculus and also seen in the late Mamluk period in the dome of Barquq inside the Hānqāh of his son Farağ at the cemetery ${ }^{71}$, and in the qibla wall of the tomb of Qaytbāy in his madrasah at the cemetery ${ }^{72}$. The domes of the Mamluks also have the same style of the qibla wall. The mihrab in the dome of Sitt Zaynab is of stone and took mainly the Mamluk design as seen in the mihrab of the dome of Barsbāy al-Bağāsī in the Mamluk cemetery $860 \mathrm{AH} / 1456 \mathrm{AD}^{73}$, and the mihrab in the dome of alĞulšani $879 \mathrm{AH} / 1474 \mathrm{AD}^{74}$. The style of the stone mihrabs with single recess, and the oculus as parts from the eastern wall could be also seen in the dome of Azrumuk 909AH/1504AD ${ }^{75}$. Thus the style of the Mamluk qibla wall is composed of the mihrab in the central lower part, the oculus over the mihrab, and the windows qandiliyāt on the flanks of the upper wall (Fig.10).In the Qibla wall of the dome of Sitt Zaynab, the same Mamluk style is applied while the mihrab is located in the middle of the wall, and is covered by a rounded oculus in the center of the upper wall (Fig.5).

\footnotetext{
${ }^{70}$ Herz. Max, La mosquée du sultan Hasan au Caire, Le Caire, 1899, P1.XIII; Abdallah M. Kahil, The Sultan Hasan Complex in Cairo 1357-1364, PhD, The Institute of Fine Arts, New York University, 2002, p.269, Pls.141,146.

${ }^{71}$ Coste. Pascal, Architecture arabe ou Monuments du Kaire, mesurés et dessinés, de 1818 à 1825, Paris, 1839, Pl.X.

${ }^{72}$ Coste, Architecture arabe, P1.XXXIII

${ }^{73}$ For the photo of the mihrab, open this link http://islamicart.org/PhotoArchive/DisplayImages.asp?photoid $=3008 \&$ qualityID $=5$

${ }^{74}$ For the photo of the mihrab, open this link http://www.islamicart.org/PhotoArchive/DisplayImages.asp?photoid=3120\&qualityID $=5$

${ }^{75}$ Open the links http://www.islamicart.org/PhotoArchive/DisplayImages.asp?photoid=3316\&qualityID=5, and the mihrab in the link http://www.islamicart.org/PhotoArchive/DisplayImages.asp?photoid=3313\&qualityID $=5$
} 


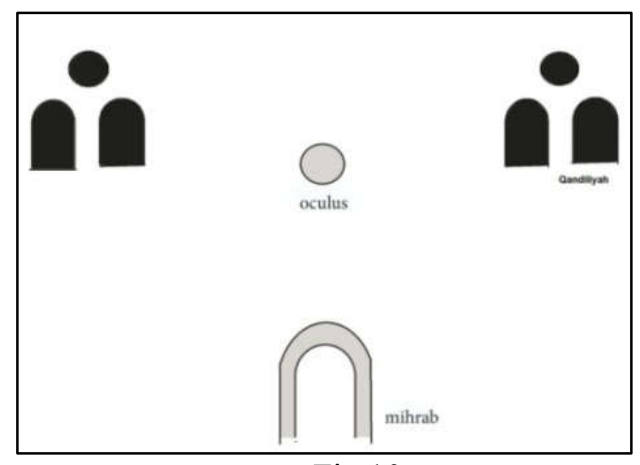

Fig. 10

The formal style of the Mamluk qibla wall

It typically resembles those of Barsbay al-Bağāsī, Ğulšanī, and Azrūmuk. Thus the style of the Qibla wall in the dome of Sitt Zaynab is typically Mamluk, and they are shown in most of the Mamluk buildings such as the domes, madrasas, and mosques ${ }^{76}$.In the northern wall of the tomb, the recess in the wall kutbiyah ${ }^{77}$ could be easily seen (Pl.VIII). When looking to the earliest domes in the Abbasid or the Fatimid period, this device is not seen apparently $^{78}$, and is shown however in the Mamluk constructions such as the

\footnotetext{
${ }^{76}$ This style of the qibla is shown in the qibla wall in most of the religious buildings such as the mosque of Šayhū al-Nāṣirī 750/1349, the qibla wall in the madrasah of sultan Hasan, the Hāanqāh of al-Nāṣir Farağ ibn Barqūq, 801-803/1359-1411, the qibla wall in the Zāwiyah of Farrağ ibn Barqūq known as zāwiyaht al-dihayšah 811/1409, the mosque of al-Mu'ayyad Šayh 818-823/1415-1420, the madrasah of al-Ašraf Barsbāy 829/1425, the madrasah of alQāđ̣̄ Yahiya Zayn al-Dīn 848/1444, the madrasah-Hāanqāh of sultan Ināl 855-860/14511456, the madrasah of Qāytbāy 877-879/1472-1474, the madrasah of Abu Bakr Muzhir 884/1379, the madrasah of Amir Kabīr Qurūmās al-Sayfĩ 911-913/1506-1507, the dome of the sultan Qanșuh Abu Sa'īd 904/1498. For more details see Munaẓamat al-'Awāṣim, Usus al-tașmìm al-mi 'mārī, pp.114,174,181,185-186, 190,197,202,208,214,230,242, Figs. 147/2,147/7,133/1/133/4,149/1,203/1,175/1,182/2,158/1,99/1,49/1,162/1,164/2. For more details on the style of the Qibla wall in the Mamluk Cairo see also Fernandez, y. Espinosa, The visual composition of the Circassian period qibla wall in Cairo. (volumes I and II). Ph.D. diss., Harvard University, 1988.

${ }^{77}$ For the term see note 47

${ }^{78}$ Many researchers such as K.A.C Creswell, Yūsuf Rāgib and Muhammad Hamzah wrote many researches on the Fatimid mausolea of Egypt whither they are for the family of the Prophet Muhammad (PBUH) or not and the never mentioned this device in any of the Fatimid domes. See Creswell, K. A. C. The Muslim Architecture of Egypt, I. Ikhshìds and Fatimids, A.D. 939-1171, Oxford, Oxford University Press, 1952; Yusuf Rāgib, Les sanctuaires des gens de la famille dans la cité des morts au Caire, Rivista de glistudi orientali, Universita di Roma, Vol. 51, Fasc. 1/4 (Giugno 1978), pp. 47-76. See also Y.
} 


\section{The Dome of al-Sayyida Zaynab bint al-Hanafiyah at the Necropolis of Bāb al-Nașr in Cairo The problem of function and dating}

dome of Azrumuk. Concerning the plan of the dome of Sitt Zaynab; it is a little bit confusing when looking at the style of the square plan (Fig.4). The square coverage is opened to only one entrance in the southwest side of the edifice. When observing the earliest domes, like that of ȚabāṬabā, it has multiple entrances seen from the remains of the plan that was given ${ }^{79}$. The Fatimid mausolea underwent various transformations, especially in the walls of the tombs, while the tombs have a square plan and more than one entrance and sometimes it reached four as seen in the Fatimid seven domes in the vicinity of al-Muqattam ${ }^{80}$. The Fatimid mausolea are varied in their number of entrances. Sometimes we have a square plan with only one entrance as seen in the domes of al-Jā'farī and Sayyida 'Ātikah ${ }^{81}$. Other Fatimid domes have a square plan with almost three entrances, especially in the Fatimid domes in Aswān ${ }^{82}$. Therefore, the Fatimid domes are varied between two to four entrances especially the domes in Aswan with almost a square plan. In the dome of Sitt Zaynab, the rule has been changed while the entrance is located in the southwest side (Fig.4); a style that comes with confusion about the date. In the Ayyubid period, the style of the plan remained with few changes, especially when looking to the plan of the dome of Imām al-Šāfi ‘'ī, it has three openings; only one use as entrance ${ }^{83}$. The square plan with three entrances also occurs in the dome of the Abbasid caliphs $640 \mathrm{AH} / 1242 \mathrm{AD}^{84}$.

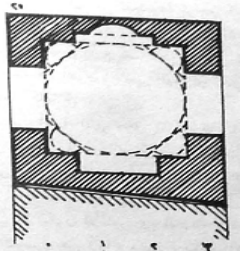

Fig.11/a

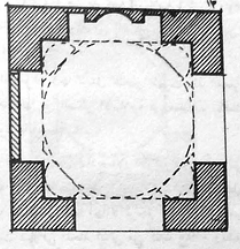

Fig. 11/b

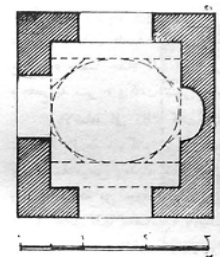

Fig. 11/c

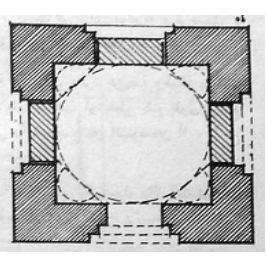

Fig. 11/d

Examples of domes with two, three, and four entrances in Aswān cemetery After Farīd Šāfi‘ī, al- 'imārah

Rāgib, Les mausolées fatimides, AnIsl, 17, pp.1-30. See also M.Ḥamza, al-Qibab, pp.55176.

${ }^{79}$ Creswell, M.A.E, I, p.12; F.Šāfi‘‘̄, al- 'Imārah, Fig.229

${ }^{80}$ Creswell, M.A.E, I, p.13, Fig. 6

${ }^{81}$ A.K.Mūsa, The Fatimid Architecture, Fig. 13

${ }^{82} \mathrm{~F}$.Šăfi'‘ 1 , al-'Imārah, pp.528-570.

${ }^{83}$ Creswell, The Muslem Architecture of Egypt, Ayyubids and Early Bahrite Mamluks, Volume II, New York, 1978 , Fig.30; Munaẓamat al-'Awāșim, Usus al-tașmīm al-mi 'mārī, P1.281/1.

${ }^{84}$ Creswell, M.A.E, II, Fig .40; A.Abd al-Rāziq, al- 'Imārah, p.199 
In the dome of al-Ṣalih Nağma 1-Dīn Ayyūb 648AH/1250AD, the plan is almost a square with only one entrance located on the northwestern corner of the interior hall ${ }^{85}$.In the Mamluk period, the design of the square plan and multiple entrances also occurred, especially the dome of Šağar al-Durr which has a square plan with three entrances ${ }^{86}$ (Fig.12/b), and the same design occurred in the dome of Faṭimah Hâtūn ${ }^{87}$ (Fig.12c). Domes with one entrance could be seen in the Circassian domes like that of the dome of Yūnus alDawādār $783-4 \mathrm{AH} / 1382 \mathrm{AD}^{88}$ (Fig. 12/d). But in other cases, the late Mamluk domes could be provided with more than one entrance with a square plan as seen in the dome of Ğānibak al-Ašrafî̀ ${ }^{89}$.
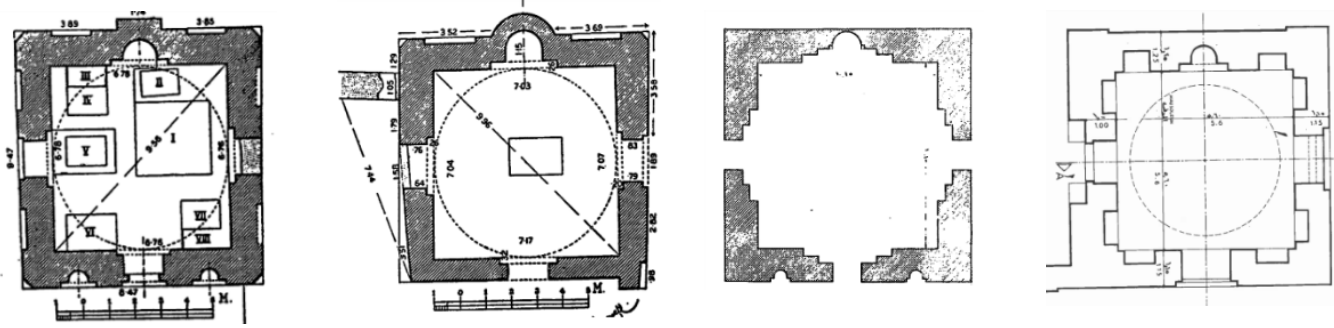

Fig.12/a Abbasid caliphs Fig.12/b Šağar al-durr Fig.12/c Fatimah Hูatun Fig.12/d Yūnus al-Dawadar, After Creswel, M.A.E, .M.Hamzah, al-Qibab After, Munazamat al-'Awāsim

In the late Mamluk period, the square design occurred with one entrance on the west side especially that in the dome of Hadijah Umm al-Ašraf 835$845 \mathrm{AH} / 1430-1440 \mathrm{AD})^{90}$, and the dome of the Rifā' $\overline{1}$ in the northern cemetery $^{91}$. In the interior design of the dome of Sitt Zaynab, the northern wall is provided with remains of a rectangular recess may be a kutbiyah or a recess for a blocked entrance (Pl.VIII). However, when observing the outer northern wall of the façade, remains of a window recess can be seen with no signs of a blocked entrance while the lintel of the opening could be observed. For that reason, one can concludes that the design of the dome resembles that of the Mamluk domes especially from the late Mamluk period as it is a dome with a

\footnotetext{
${ }^{85}$ M. Ḥamzah, al-Qibāb, Fig. 8;Munaẓamat al-'Awāṣim, Usus al-tașmīm al-mi 'mārī ,p.69; Pl.38/1;A.Abd al-Rāziq, al-'Imārah, p.203.

${ }^{86}$ Creswell, M.A.E, II, Fig.71; Munaẓamat al-'Awāșim, Usus al-tașmīm al-mi 'mārī ,p.77; Pl.169/1.

${ }^{87}$ M. Hamzah, al-Qibāb, Fig.9

${ }^{88}$ Munaẓamat al-'Awāṣim, Usus al-tașmìm al-mi 'mā̄ī ,p.141, Pl.157/1

${ }^{89}$ M. Hamzah, al-Qibā b, fig.36

${ }^{90}$ H.Hamzah, Northern Cemetery, Fig.6

${ }^{91}$ M. Hamzah, al-Qibāb, fig.38
} 


\section{The Dome of al-Sayyida Zaynab bint al-Hanafiyah at the Necropolis of Bāb al-Nașr in Cairo The problem of function and dating}

square plan and only one entrance. Finally the researcher found a small slab of marble carrying three lines of inscriptions in nashī. The style of nashī writing was never found before the $6^{\text {th }} \mathrm{AH} / 12^{\text {th }} \mathrm{AD}$ century. When we look at the slab (Pl.XII), the upper part and some traces of the lower edge have been lost, only some traces of the letters had been preserved. From the style of the letters, it was inscribed in the Mamluk or the Ottoman period during the restoration of the dome or maybe it was an addition that was added in modern times in the time of Muhammad Ali's dynasty or later. The last thing we have to mention is the material; by observation, the inner layer of building masonry is or burnt brick al-Ağur; the type of bricks that was used mainly in the first two centuries AH. In the mosque of 'Amr ibn al-'Ạs for example the material was uses during the renovation by the Umayyad governor Qurra ibn Šrayk in $93 \mathrm{AH} / 712 \mathrm{AD}^{92}$, and it is used widely in the mosque of Aḥmad ibn Ṭulūn and continues to be used in the Fatimid period ${ }^{93}$. Here in the tomb of Sitt Zaynab, each part of the walls are embedded with full course of burnt bricks which gives us evidence about the time of the construction. It means that the dome was built before the $6^{\text {th }} \mathrm{AH} / 12^{\text {th }} \mathrm{AD}$ century because the stone was known in the constructions for the first time in the western façade of the mosque of alHākim bi'Amr Allah ${ }^{94}$ especially in the minarets ${ }^{95}$. The Ayyubid and Mamluk domes were made of full stones as can be observed in the cemeteries or in the vicinity. Thus it is unlikely to consider that this dome was built in the Mamluk period; we might assume though that Mamluks renovated the structure and added own elements to the dome. The plan of the dome therefore changed in the times by the Mamluks but the dome was present before.

\section{Conclusion}

After studying the dome and its architectural analysis; one can concludes that this dome was built in two distinct periods. The first period is the third century $\mathrm{AH} / 9^{\text {th }} \mathrm{AD}$ and this is the period when the lady came to Egypt as

\footnotetext{
${ }^{92}$ Creswell.K.A.C, La mosquée de 'Amru [avec 12 planches] traduit de l'anglais par Mme R. L. Devonshire, Bulliten de l' Institut français d'archéologie orientale BIFAO- Le Caire, 32 (1932), p.124 ; A.Abd al-Rāziq, al-'Imārah, p.49

93 al-Maqrīzī, al-hitat, Edited by Ayman Fu'ad Sayid, Vol.IV, Pt.I, p.64; Maḥmūd 'Akūš, Tārīh wa wașf al-ğāmi' al-țūlūnī, Cairo, 1927, pp.37-39; A.Abd al-Rāziq, al- 'Imārah, p.49.

${ }^{94}$ A.Abd al-Rāziq, al- 'Imārah, p.49.

${ }^{95}$ D.Abu Seif, Islamic Architecture, p.64
} 
mentioned before; the second period is the Mamluk period from the $7^{\text {th }} \mathrm{AH}$ to the $9^{\text {th }} \mathrm{AD}$ and this for many reasons:

1-The name of the common people for this monument is obviously ma 'bad al-sitt Zaynab which means that this monument was used as a place for worshiping for a particular tariqah for Sufis as witnessed also in the ma bad of Sīdī Aḥmad al-Rifă'ī which is located nearby the Hānqāh of al-Ašraf Barsbāy in the northern Mamluk suburb of Cairo ${ }^{96}$. Therefore, the tomb of Sitt Zaynab was used as a ma 'bad or place for worshipping by Sufis mainly starting with the Mamluk period.

2-The style of the upper oval construction of the dome gives an interpretation of the style of the third century AH, like the Persian domes and the dome of ȚabāTabā in Egypt while the upper half circle spanning the center of the dome makes an oval shape not a half circle.

3-The style of the oval windows on the basement of the half circle is a style that occurred mainly in the domes of the $3^{\text {rd }}$ century $\mathrm{AH}$ and extended to the fourth found also in many of the Fatimid domes in Egypt and outside.

4-The style of the stalactites as transitional zones is very simple with semicircular pointed arches, void of any decoration. The style that occurred in the early domes of the third century AH, also in the fourth to the fifth centuries $\mathrm{AH}$. This indicated that the interior design of the dome was made during the early three centuries before the Ayyubid and the Mamluk period. The style of the Ayyubid and the Mamluk transitional zones is different and contains more than one row of stalactites

5-The material of the masonry dome is the brick which is used in the early four centuries of Hijra as mentioned before, so the dome's walls are embedded with courses of bricks in its three parts: the upper dome - the octagonal drum, and the four walls.

6-The dome's outer wall was once surrounded by a course of crenellation in trilobed forms which means that the dome was restored in the Mamluk period; only some traces now could be seen in the northern and the western facades of the dome, and they are made of stone different from the masonry dome itself.

7- The dome is mainly provided with a style of windows that occurred in the Mamluk period which is the qandīliyāt as can be observed in the northern, western and the southern facades. This style of windows never occurred before the Mamluk period which means that those windows were added to the tomb in the Mamluk period. The material of windows is also different from the masonry dome itself.

\footnotetext{
${ }^{96}$ For more details, See Frenandes. Leonor, Three Șūfĩ Foundations in a 15th Century Waqfiyya, Annales Islamologiques, Le Caire, 17 (1981), pp.146-150.
} 


\section{The Dome of al-Sayyida Zaynab bint al-Hanafiyah at the Necropolis of Bāb al-Nașr in Cairo The problem of function and dating}

8-The style of the qibla wall appeared also in the Mamluk period which is the central mihrab surmounted by the oculus. When looking at the mihrab, the inner course of bricks can be seen, while also some traces of the outer plaster revetment appear. That gives us a conclusion that this mihrab is the original mihrab of the dome, and the outer mortar and the oculus were added to the dome. That is because of the inner masonry of the mihrab which is the bricks and the outer casing of mortar was added in the Mamluk period.

9-Few changes were made to the actual mihrab. The style is in a form of a recess with semi-circular arch and once flanked by two columns; only the place of the columns remained. By observing the main mihrab of the qibla wall, the style is apparent in the early Islamic constructions. The style here could be seen in the Mamluk Domes especially those in the Mamluk cemetery such as the mihrab in the dome of Barsbay al-Bağāsī, and the dome of al-Ğulšanī as mentioned before.

10-One of the Mamluk features of the dome is the recess of the northern side of the tomb chamber which could be a recess for a window or a kutbiyah for the books. The recess is now blocked; only a window with circular openings was put on the outer side.

11-The plan of the dome is almost square which is shown on the early Fatimid domes. It seems that the plan slightly changed in the Mamluk period, while only one entrance is provided on the southwestern wall of the dome chamber.

12-The dome of al-Sayyida Zaynab wasn't used only as a grave. Several circles of $\underline{d i k r}$ were held for the Sufis and also the halaqah was organized according to the rituals of the Sufis. That's because of the existence of the quran reader's chair (Figs.6,7), and they were used by the šayh for giving the lessons to his disciples, and the chairs were shown in the Mamluk hāanqās for Sufis such as the Hānqāh of al-Ašraf Barsbāy in his dome, the Hēanqāhmadrasah of sultan Qāytbāy at the cemetery. This device was also used in the mosques and seen in the mosque of Qānībāy al-Rammāh. When saying that the style of the chairs wasn't Mamluk that means that the Sufi rituals continued even after the end of the Mamluk period and went on in the Ottoman times.

13-In the dome a slab of marble was found carrying nashī inscriptions first published by the researcher. The text is clarifying invocations and supplications like demands from the deceased to his visitors (Pl.XII) (Fig.7/a). The style of writing is somehow applied in later times may be in the Ottoman or in the modern ages. 
To sum up, the dome of al-Sayyida Zaynab at Bab al-Nașr cemetery is considered one of the unique structural domes in the Islamic period because of its formation and style that is rarely to be found in the Islamic monuments of Cairo. So we can conclude that this dome was built within the $3^{\text {rd }}$ century $\mathrm{AH}$, when, the rulers and sultans venerated the lady and its mašihad or darīh. Because of the importance of the place the Mamluks had restored the dome although it was made as a grave for one of the $\overline{A l}$ al-Bayt who came to Egypt in the $212 \mathrm{AH} / 827 \mathrm{AD}$ or $213 \mathrm{AH} / 828 \mathrm{AD}$ with her brother, while the year of her death was unknown. So the Mamluks hadn't taken the doctrinal point of view into their consideration when they restored the dome otherwise they would have demolished the dome as occurred in turbat al-za farān in the time of the Circassian sultan al-Zāhir Barqūq. By this conclusion, this dome may be the oldest grave in Egypt being venerated by the Mamluk sultans who had mostly given their awareness to the hawš al-șufiyah especially from the time of the Mamluk sultan al-Nāṣir Muhammad ibn Qalāwūn who had developed this area but later abandoned it and the cemetery in $720 \mathrm{AH} / 1320 \mathrm{AD}$. In this area which is called al-Rayidāniyah or Maydān alqabaq as mentioned by al-Maqrīzī. He noted as well that the first Mamluk who built his tomb here was Šams al-Dīn Qarāsunqur joining the tombs of Sufis turab al-süfiyah. Later on more Mamluks added their tombs. So the turab al-süfiyah, and the tomb of Sitt Zaynab al-Hanafiyah had raised the awareness of the Mamluks sultans and emirs also the Mamluk such as Sayf al-Dīn Kūkāy, Țājār al-Dawādār, Sayf al-Dīn Țaštumur al-sāqī, prince Mankalībuġā who also developed the area and built graves.

The area was also inhabited and developed in the Circassian period by sultan al-Zāhir Barqūq and his son Farağ ${ }^{97}$. This argument moved us to a conclusion that this dome after it had been built within the $3^{\text {rd }}$ century $\mathrm{AH} / 9^{\text {th }}$ $\mathrm{AD}$ was restored and renovated by the Mamluks who had also their burials in the sahara $\bar{a}^{\prime}$ either in the north or in the south cemeteries started from $b \bar{a} b$ al-barqiyah up till the cemetery of bāb al-wazìr and Sìdī Ğalāl to the south vicinity of Cairo, ${ }^{98}$, and built their burials in the cemeteries, so it is logic to say that they were keen on representing their generous care to the

\footnotetext{
${ }^{97}$ al-Maqrīzī, al-hițat, Edited by Ayman Fu'ad Sayid, Vol.IV, Pt.II, pp.918-921.

${ }^{98}$ For more details see H.Hamza, The Northern Cemetery, pp.1-18.
} 


\section{The Dome of al-Sayyida Zaynab bint al-Hanafiyah at the Necropolis of Bāb al-Nașr in Cairo The problem of function and dating}

constructions of the $\overline{A l}$ al-bayt, as seen in the dome of Imām al-Šăfi‘'̄ which has been given a special awareness by the Mamluk sultans Qāytbay and alGawri $^{-99}$.

\section{-Arabic sources and references}

-The Holly Quran

-'Abd al-Rāziq. Aḥmad, al-Funūn al-Islāmiyah hata nahāyat al-'Aṣr al-Faṭimī, Cairo, 2006, p.192

..... al-'Imārah al-Islāmiyah fì Miṣr mund̄u al-fatḥ al-'arabì ḥata nahāyat al-'aṣr al-mamlūkī, Cairo, 2012,

-Abu Kaff, Aḥmad, Āl Bayt al-nabīf ì Mișr, Cairo, 1988.

-‘Akūš .Maḥmūd, Tārīh wa wașf al-ğāmi' al-țūtūnī, Cairo, 1927

-al-Azharī .Tartwat Fatḥ̄, Gabantbāb al-Naṣr war u'iyā šāmilah li wad'aha 'alā harītat al-siyāḥa al-diniyahwa-l-iršād al-siyāḥ̄, PH.D thesis, Faculty of Tourism and Hotels, Menia University, 2016.

- Delly. Wilfred Joseph, al-'Imārah al-'arabiyah bi Miṣr, fišsarḥ al-mumayzāt albinā'iyah al-ra'̄isiyah li-l-țirāz al- 'arabī, Cairo, 1923.

-Hamzah .Muhammad, al-Qibab fi-l-'Imarah al-Mișriyah al-Islāmīyah, Cairo, 1993 Silsilat al-ğabbānat fi-l- imarah al-islāmiyah, waQarafat al-

Qāhirah mi al-fatḥ al-islāmīilanahāyat al-'așr al-mamlūkī, Cairo, 2006.

-al-Hāritīi .Huwayda, Kitāb waqf al-sultān Hasan bin Muhammad ibn Qalāwūn 'alā madrasatihī bi-l-Rumaylah, Bairut, 2001.

- Hasanayn .Mamdūḥ Muḥammad, al-Mašāhid al-bāqiyah fi-l-'Așr al-Fāṭimī, M.A, Faculty of Archaeology, Cairo, University, 2003

- Ibrahim. Layla. A, al-Muștalāḥāt al-mi 'mārīyah fi-l-wațā'iq al-mamlūkīyah, The American University in Cairo, 1990.

- Ibrāhīm .Muḥammad Zakī, Marāqid Ahl al-Bayt fi-l-Qāhirah, Cairo, 2003

- al-'Imarī .Amāl, al-'Imarah al-fațimiyah, no date

- al-Maqrīzī, al-Mawā'iz wa-l-i'tibar bi dikr al-hitat wa-l-Ātār, Released by Ayman Fu'ad Sayid, Vol,IV, Pt.II, London, 2003.

- Munazamat al-'awașimwa-l-mudun al-Islāmiyah, Usus al-tașmīm al-mi 'mārī wa-ltahțīt al-ḥaḍarī fi-l-'uṣur al-islāmiyah al-muhtalifah bi-l-'āṣimah al-Qāhirah, Cairo, 1990.

- Mușțafa .Ṣāliḥ Lam‘̄i, al-Qibāb fi-l- 'Imārah al-Islāmiyah, Cairo, no date.

- Qāsim. Hasan, al-Mazārāt al-Islāmiyah, Bibliotica Alexandrina, 2018.

${ }^{99}$ For more details see Creswell, M.A.E, II, pp.73,74; Mulder. S, The Mausoleum of Imam Al-Shafi' i, Muqarnas,23, pp.41,42. 
- al-Sahāwy, Tuhfat al-aḥbāb wa bugìyat al-tullāb fi-l-hitat wa-l-mazārāt wa-l-biqā ' al-mubārakāt, Released by Hasan Qāsim, Mạ̣mūd Rabīì , Cairo, 1937.

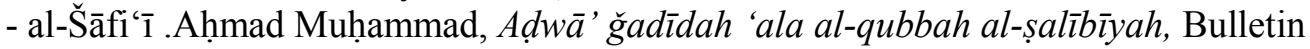
of the Faculty of Arts, Sohag University, April, Volume I. 2018, No,47.

- Šāfi'‘̄ .Farīd Šāfi'‘̄, al-'Imārah al-'arabiyah fì Miṣr al-Islāmiyah, 'Aṣr al-wullāh, General Egyptian Book Organization, Cairo, 1994.

- al-'Ubaydalī al-Nassābah, Tārīh wa manāqib wa ma'ātir al-sitt al-tāhirah al-batūl al-Sayida Zaynab wa ahbār al-zaynabāt, released by Hasan Qāsim, Cairo, 1934.

- Ibn 'Uțmān. Muwafaq al-Dīn, Muršid al-zuwwār ila qubūr al-abrār, Released by Muhammad Fathī Abu Bakr, Cairo, 1995

- Zambaur. Edward Von,Mu '̌gam al-ansāb wa-l-usrāt al-hākimah fì-l-tārīh alIslāmī, Beirut, 1980

- Ibn al-Zayyiāt, al-Kawākib al-sā̄yyārah fì tartīb al-ziyārah fi-l-qarāfatayn alkubrawa-l-ṣugra, Cairo, 1907.

\section{-Foreign references}

- Abd al-Rāziq .Ahmad, Un collège féminine dans l'Egypte Mamluke, Journal of the Faculty of Archaeology, Cairo University, Part III, 1987.

- Abu Seif .Doris. B., Islamic Architecture, An Introduction, AUC, Cairo, 1989.

- Ashkan, Maryam. \& Ahmad, Yahaya, Discontinuous Double-shell Domes through Islamic eras in the Middle East and Central Asia: History, Morphology, Typologies, Geometry, and Construction, Nexus Network Journal - Vol.12, No. 2,Turin, 2010.

- Bloom. Jonathan M, The Introduction of the Muqarnas into Egypt, Muqarnas, Brill, Vol. 5 (1988)

- Briggs. Martin.S, Muhammadan Architecture in Egypt and Palestine, Oxford, 1924.

- Cipriani. Barbara, Development of the Construction Techniques in the Mamluk Domes of Cairo, M.A, Massachusetts Institute of Technology, 2005.

- Creswell, K. A. C La mosquée de 'Amru [avec 12 planches] traduit de l'anglais par Mme R. L. Devonshire, Bulletin de l'Institut français d'archéologie orientale BIFAO- Le Caire, 32 (1932)

-. -----------------The Muslim Architecture of Egypt, Volume. I. Ikhshīds and Fātimids,

A.D. 939-1171, Oxford, Oxford University Press, 1952.

- ------- The Muslim Architecture of Egypt, Ayyubids and Early Bahrite

Mamluks, Volume II, New York, 1978

- Coste. Pascal, Architecture arabe ou Monuments du Kaire, mesurés et dessinés, de 1818 à 1825, Paris, 1839, P1.X.

- Espinosa, Luisa. Maria, The visual composition of the Circassian period qibla wall in Cairo. (volumes I and II). Ph.D. diss.,Harvard University, 1988.

- Goussous .Jawdat, Wael al-Azhari, Domes Formation in Mediterranean Islamic Countries, Conference: "DOMES IN THE WORLD" International Congress November 3-6, Florence, ITALY, 2011.

- Gye. D. H., "Arches and Domes in Iranian Islamic Buildings: An Engineer's Perspective." Iran, vol. 26, 1988.

- Hamza. Hānī, The Northern Cemetery of Cairo, The American University in Cairo, 2001

- Herz. Max, La mosquée du sultan Hasan au Caire, Le Caire, 1899.

- Ibrahim.Layla.A, The Transitional Zones of Domes in Cairene Architecture, Kunst des

Orients, Franz Steiner Verlag, Vol. 10, H. 1/2 (1975) 


\section{The Dome of al-Sayyida Zaynab bint al-Ḥanafiyah at the Necropolis of Bāb al-Nașr in Cairo The problem of function and dating}

- Kahil. Abdallah M., The Sultan Hasan Complex in Cairo 1357-1364, PhD, The Institute of Fine Arts, New York University, 2002.

- El-Khateeb .Ahmad Ali , Domes in the Islamic Architecture of Cairo city, A Mathematical Approach, in Nexus Netw J 14, Vol.14, No.1, Turin , Jan.2012

- Mulder.Stephennie, The Mausoleum of Imam Al-Shafi i, Muqarnas,Vol. 23 (2006).

- Mūsa. 'Abdallah Kamil, The Fatimid Architecture in Cairo, Cairo, 1995.

- Northedge Alastair "An Interpretation of the Palace of the Caliph at Samarra (Dar AlKhilafa or Jawsaq Al-Khaqani)." Ars Orientalis, Freer Gallery of Art, The Smithsonian Institution and Department of the History of Art, University of Michiganvol. 23, 1993

- O'Kane, Bernard. "The design of Cairo's masonry domes." Proceedings of the Masons at Work Conference. University of Pennsylvania, 2012.

- Pruitt Jennifer. A, Fatimid Architectural Patronage and Changing Sectarian Identities (9691021), PhD, Harvard University, 2009.

- al-Qādīi. Galīla, Alain Bonnamy, Architecture of the Dead, Cairo's Medieval Necropolis, AUC, Press, Cairo, 2007.

- Rāg̀ib .Yusuf, Les mausolées fatimides du quartier d'al-Mašāhid, Annales Islamologiques IFAO, Tome 17. Le Caire, 1971.

- -------- Les sanctuaires des gens de la famille dans la cité des morts au Caire,

Rivista de glistudi orientali, Universita di Roma, Vol. 51, Fasc. 1/4 (Giugno 1978).

- El Sandouby, A.,Ezzeldin Ismail, The Ahl al-Bayt $n$ Cairo and Damascus: The dynamics of making shrines for the family of the prophet, PHD,University of California, Los Angeles, 2008 .

- Shimmel, Annemarie, Calligraphy and Islamic Culture, New York, 1984.

- Swelim. Muhamad Tarek Nabil, The Mosque of IbnṬūlūn, A new perspective, PhD, Harvard University, 1994

-IbnTulun, His Lost City and Great Mosque, AUC, Cairo, 2015

- Thomas. Edward and Mary Eliza, Syemour, George.L, Cemeteries and Mosque Tombs, Cairo, The Art Journal (1875-1887), New Series, Vol. 6 (1880).

- Williams, Caroline. "The Cult of 'Alid Saints in the Fatimid Monuments of Cairo Part II:,The Mausolea.” Muqarnas, vol. 3, 1985.

\section{-Internet links and websites}

- http://www.islamic-art.org/CreswellExhibition/index.htm

- Creswell Photo Archive in the Ashmolean Museum.

http://creswell.ashmus.ox.ac.uk/archive/EA.CA.4406-0

-http://islamic-art.org/PhotoArchive/DisplayImages.asp?photoid=3008\&qualityID=5

-http://www.islamic-art.org/PhotoArchive/DisplayImages.asp?photoid=3120\&qualityID=5

-http://www.islamic-art.org/PhotoArchive/DisplayImages.asp?photoid=3316\&qualityID=5

-http://www.islamic-art.org/PhotoArchive/DisplayImages.asp?photoid=3313\&qualityID=5 
Salah al-Dīn, W

\section{The Plates}

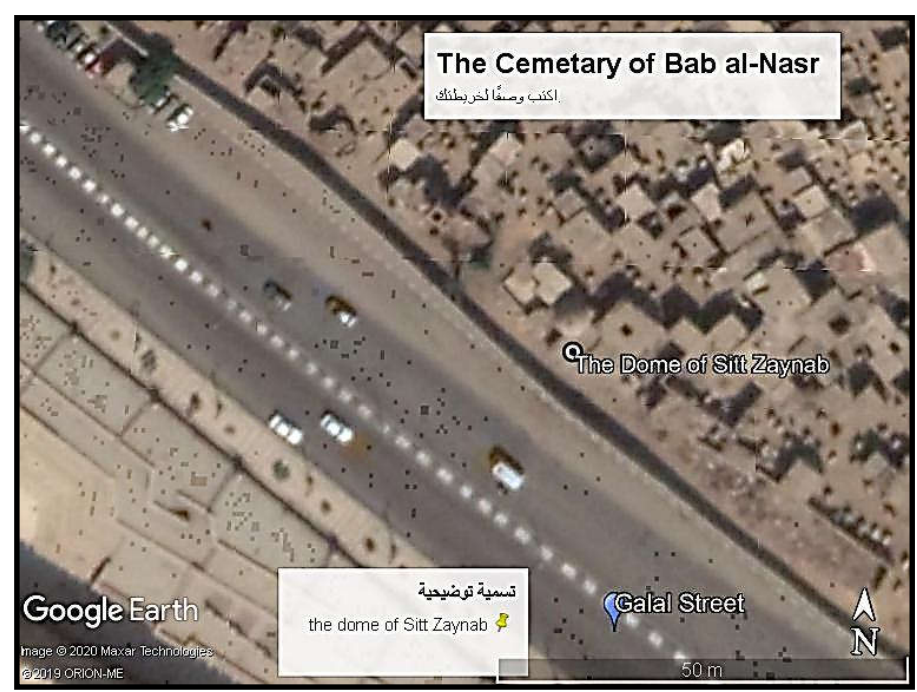

P1.I

After google earth 2020

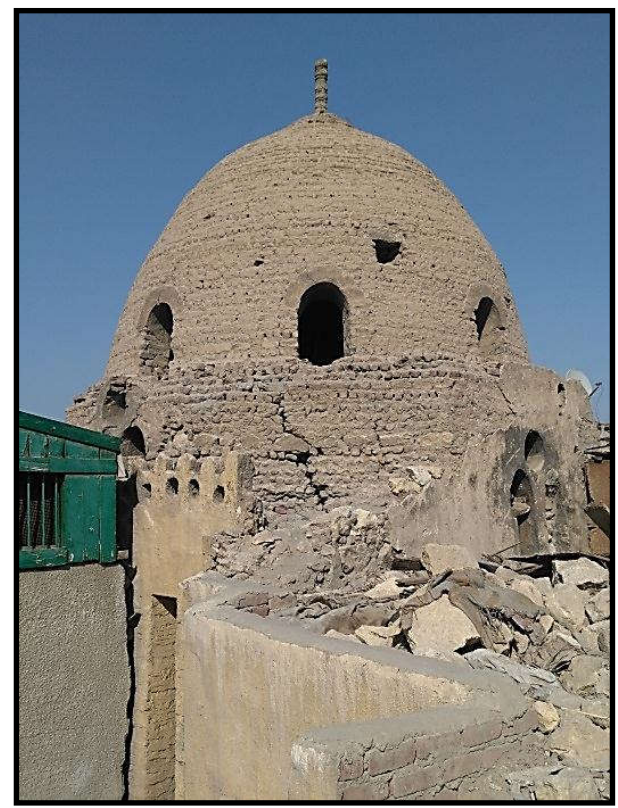

Pl.III

The western façade

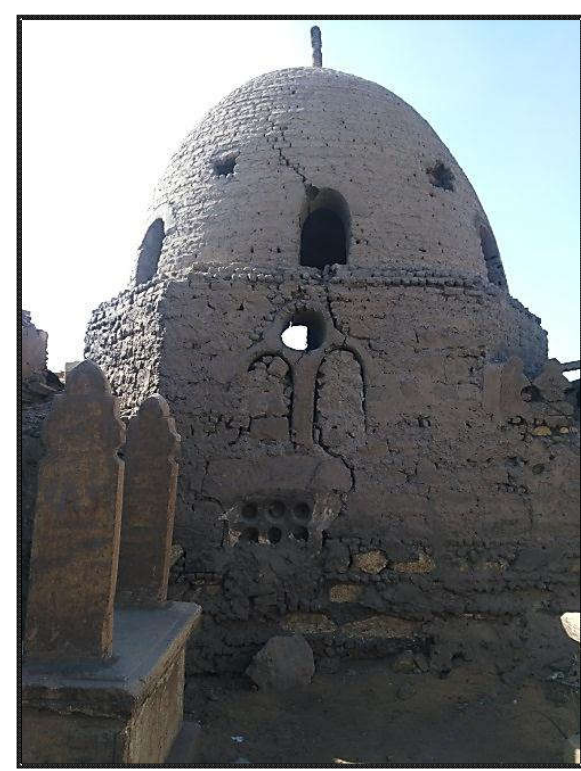

P1.II the northern façade

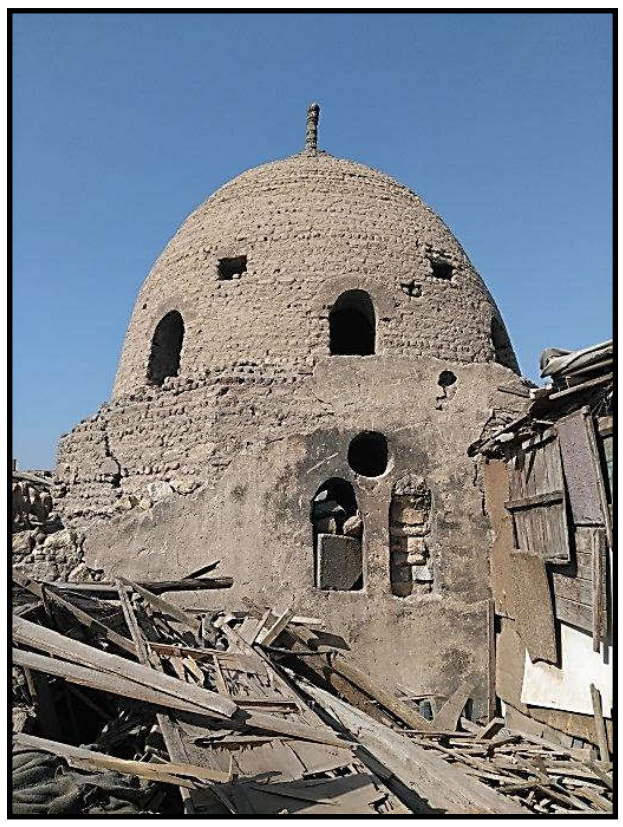

Pl.IV

The southern façade

Photographed by the researcher 
The Dome of al-Sayyida Zaynab bint al-Hanafiyah at the Necropolis of Bāb al-Nașr in Cairo

The problem of function and dating
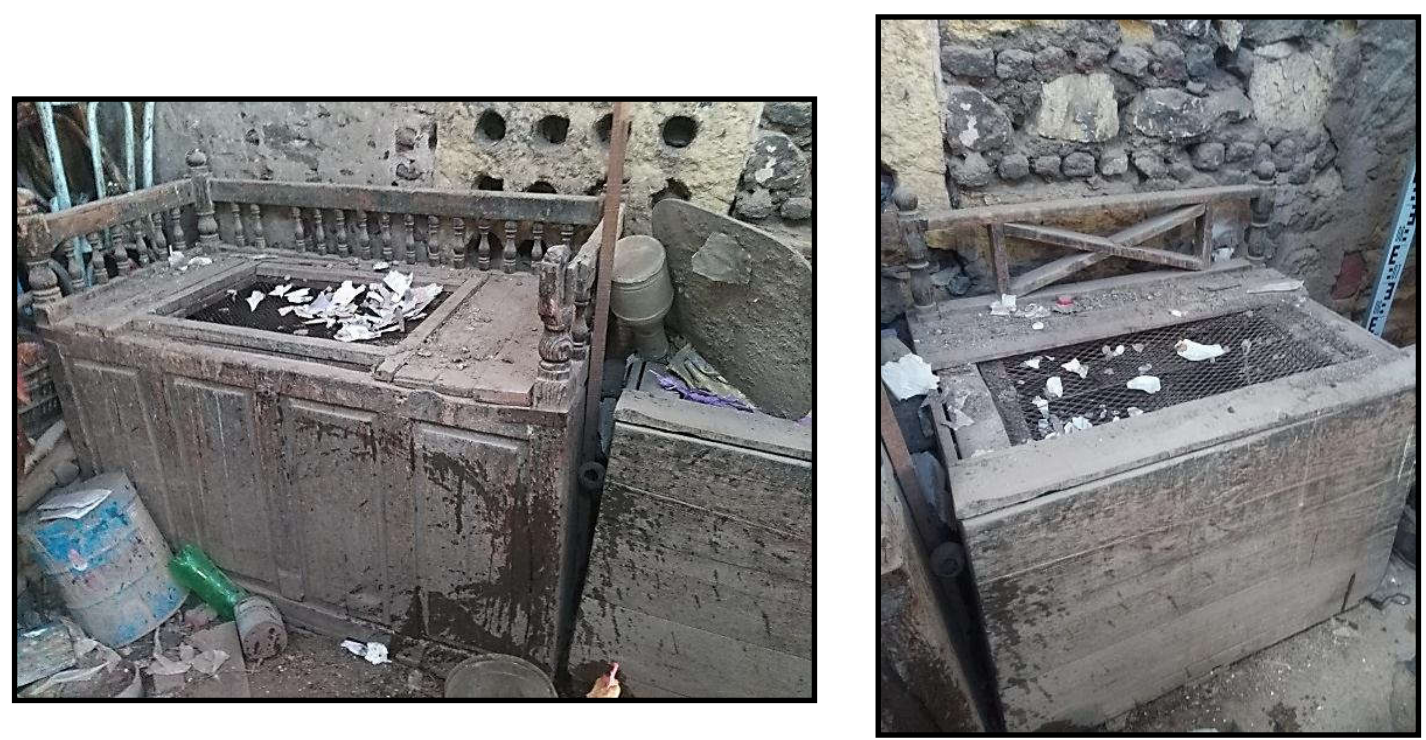

Pl.V

Pl.VI

Chairs in the southern part

Photographed by the researcher

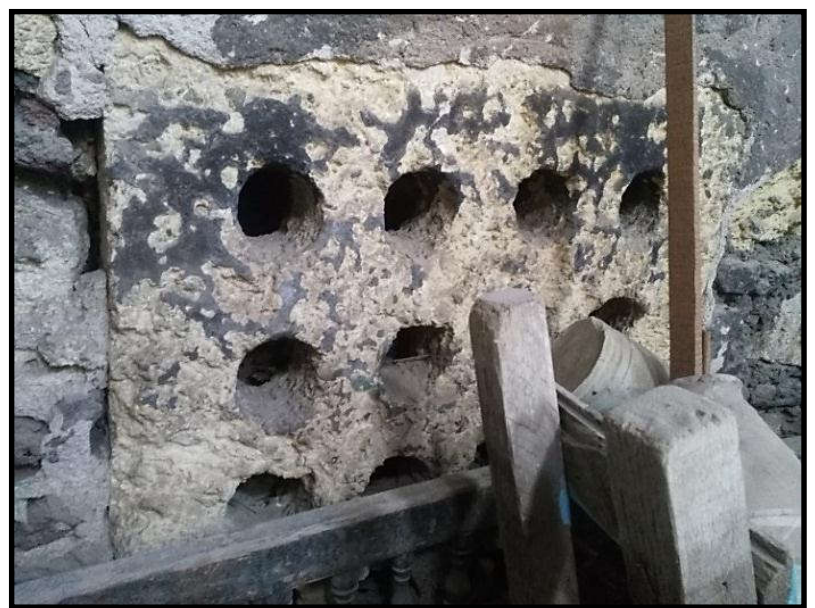

Pl.VII

A window opining in the southern wall

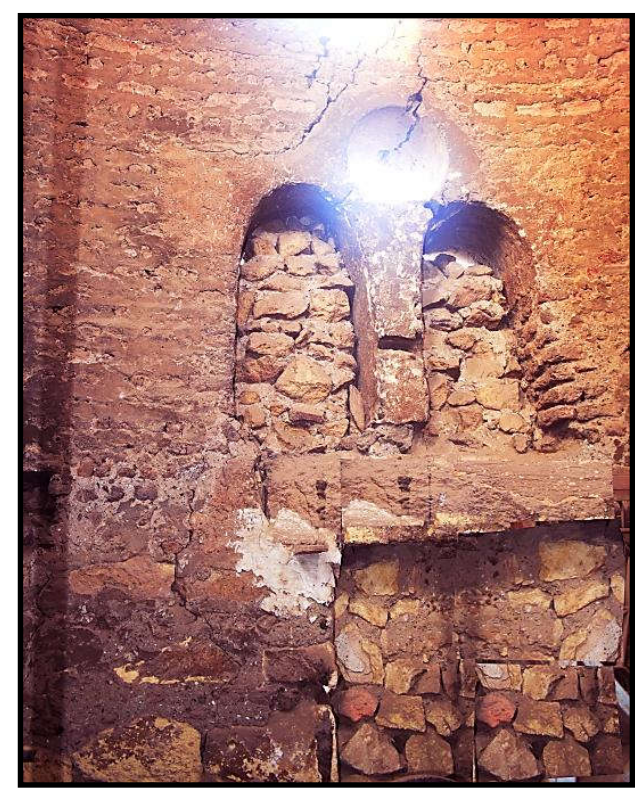

Pl.VIII

The northern wall

Photographed by the researcher 
Salah al-Dīn, W

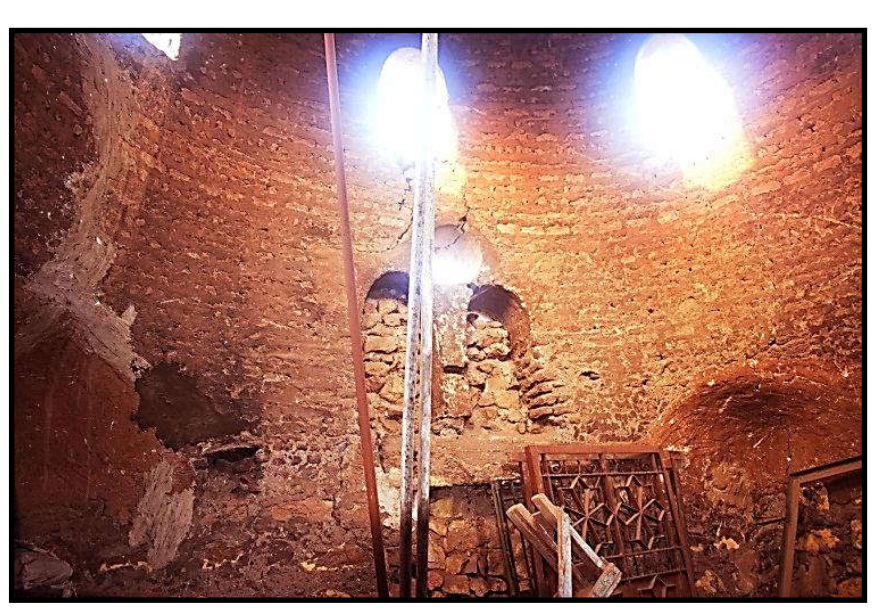

P1.IX

Squinches in the northern wall

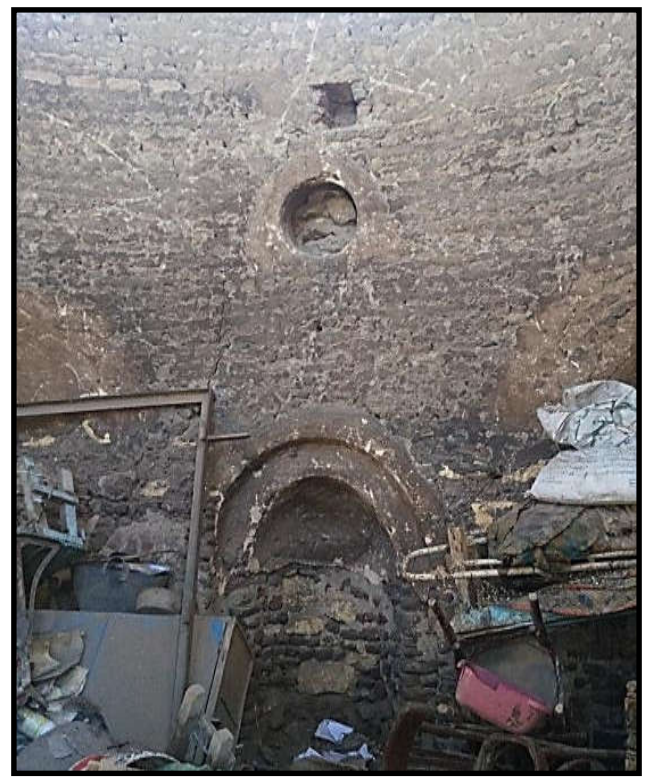

P1.X

The mihrab and the Qibla wall

Photographed by the researcher

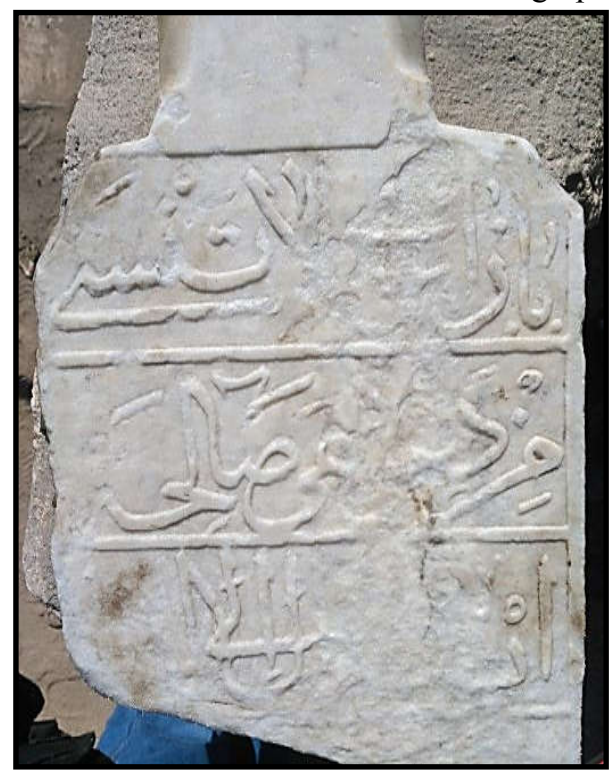

Pl.XII

Marble slab contains inscriptions

Photographed by the researcher

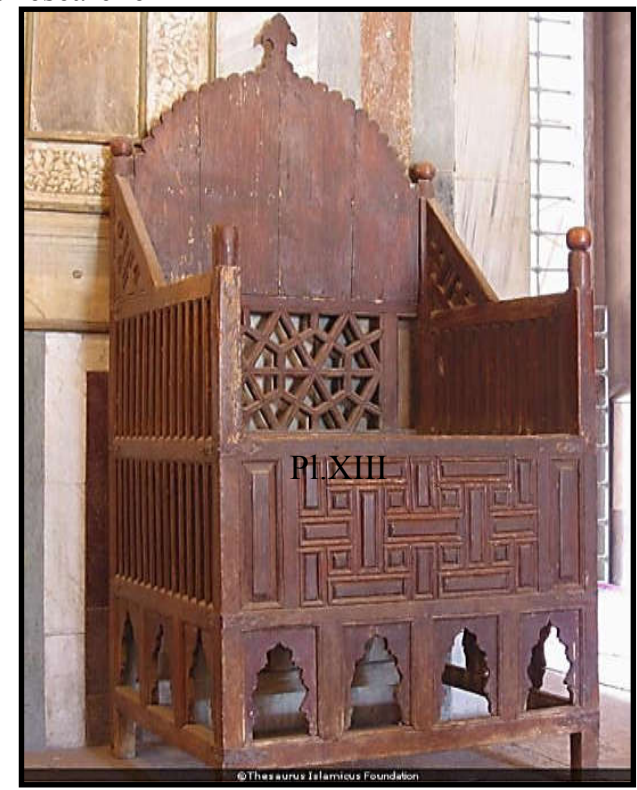

P1.XIII

a chair for the quran reader in the

Dome of the madrasah of

Sultan Hasan

After.www.islamic-art.org 


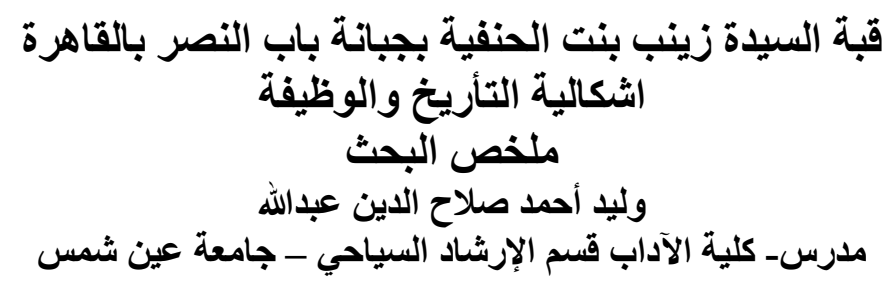

ترجع أهمية البحث هنا إلي محاولة تأريخ هذه القبة الفريدة الطر از حيث انها صنفت من القباب

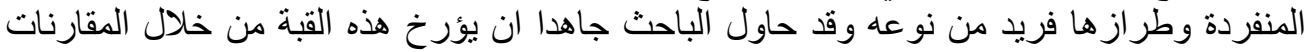

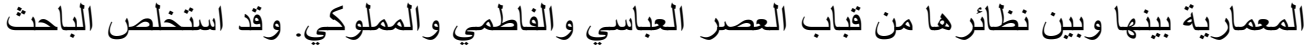

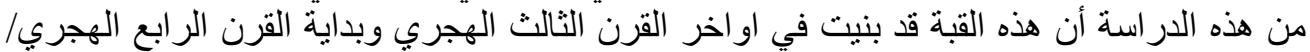

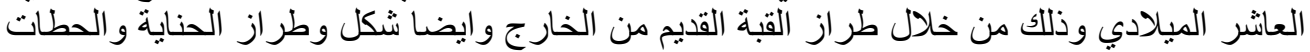

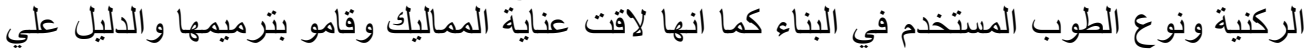

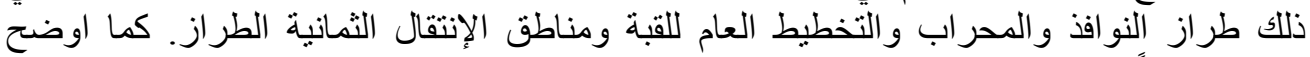

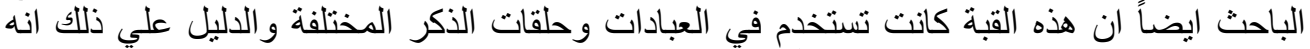

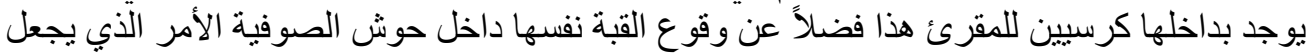

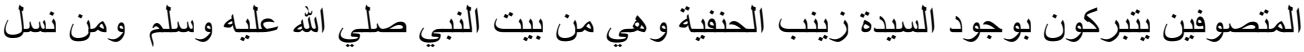

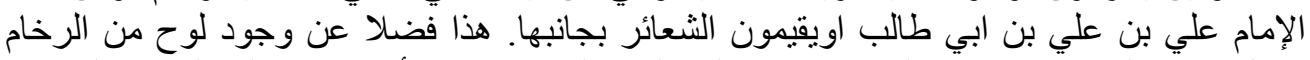

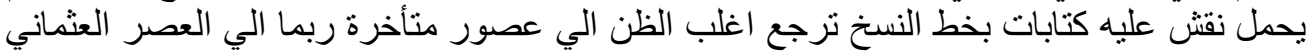

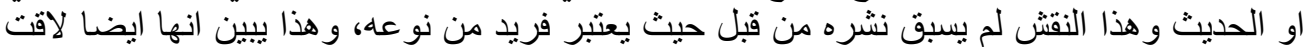

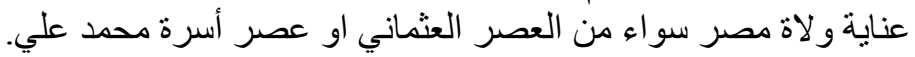
الكلمات الاالة: القبة ـ العمارة الإسلامية ـ الآثار الإسلامية 